DOE NASA CONTRACTOR REPORT

\title{
SOLAR HOT WATER DEMONSTRATION PROJECT AT RED STAR INDUSTRIAL LAUNDRY, FRESNO, CALIFORNIA - FINAL REPORT
}

Prepared by

Aratex Services, Incorporated

16001 Ventura Boulevard

P. O. Box 3000

Encino, California 91316

Under DOE Contract EX 76-C-01-2384

Monitored by

National 4eronautics and Space Administration

George C. Marshall Space Flight Center, Alabama 35812

For the U. S. Department of Energy

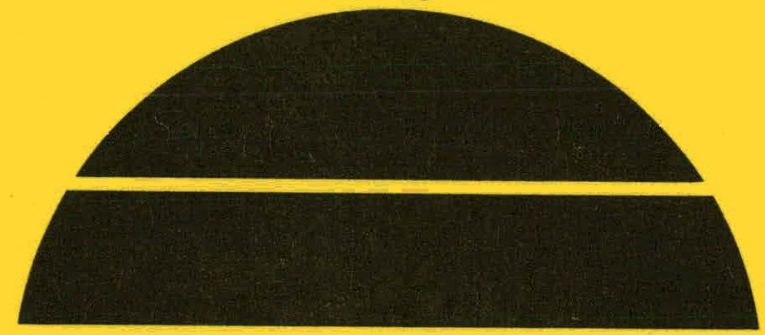

\section{U.S. Department of Energy}




\section{DISCLAIMER}

This report was prepared as an account of work sponsored by an agency of the United States Government. Neither the United States Government nor any agency Thereof, nor any of their employees, makes any warranty, express or implied, or assumes any legal liability or responsibility for the accuracy, completeness, or usefulness of any information, apparatus, product, or process disclosed, or represents that its use would not infringe privately owned rights. Reference herein to any specific commercial product, process, or service by trade name, trademark, manufacturer, or otherwise does not necessarily constitute or imply its endorsement, recommendation, or favoring by the United States Government or any agency thereof. The views and opinions of authors expressed herein do not necessarily state or reflect those of the United States Government or any agency thereof. 


\section{DISCLAIMER}

Portions of this document may be illegible in electronic image products. Images are produced from the best available original document. 
This report was prepared to document work sponsored by the Unfted States Government. Ne1ther the Unfted States nor 1ts agents the United States Department of Energy, the United States National Aeronautics and Space Administration, nor any federal employees, nor any of their contractors, subcontractors or the1r employees, make any warranty, express or 1mpl1ed, or asaume any legal liabllity or responstbllity for the accuracy, completeness, or usefulness of any information, apparatus, product or process disclosed, or represent that 1ts use would not infringe privately owned rights. 
TECHNICAL REPORT ST ANDARD TITLE PAGE

\begin{tabular}{|c|c|}
\hline $\begin{array}{l}\text { 1. REPORT NO. } \\
\text { DOE/NASA CR- } 161537\end{array}$ & 3. RECIPIENT'S CATALOG NO. \\
\hline \multirow{2}{*}{$\begin{array}{l}\text { 4. TITLE ANo subTitle } \\
\text { Solar Hot Water Demonstration Project at Red Star } \\
\text { Industrial Laundry, Fresno, California }\end{array}$} & $\begin{array}{l}\text { 5. REPORT DATE } \\
\text { July } 1980\end{array}$ \\
\hline & 6. PERFORMING ORGANIZATION CCIDE \\
\hline 7. AUTHOR(S) & 8. PERFORMING ORGANIZATION REPARI \\
\hline \multirow{3}{*}{$\begin{array}{l}\text { 9. PERFORMING ORGANIZATION MAME AND ADDRESS } \\
\text { ARATEX Services, Incorporated } \\
\text { 16001 Ventura Boulevard, P.0. Box } 3000 \\
\text { Encino, California } 91316\end{array}$} & 10. WORK UNIT NO. \\
\hline & $\begin{array}{l}\text { 11. CONTRACT OR GRANT NO. } \\
\text { EX-76-C-01-2384 }\end{array}$ \\
\hline & 13. TYPE OF REPOR $I$ Q $Q$ PERIOO COVEREO \\
\hline \multirow{2}{*}{$\begin{array}{l}\text { 12. SPONSORING AGENCY NAME ANO AOORESS } \\
\text { U.S. Department of Energy } \\
\text { Conservation and Solar Energy } \\
\text { Washington, DC } 20585\end{array}$} & $\begin{array}{l}\text { Contractor Report - } \\
\text { Final }\end{array}$ \\
\hline & 14. SPONSORING AGENCY CODE \\
\hline
\end{tabular}

This work was done under the technical management of $\mathrm{Mr}$. E. Roger Teague,

George C. Marshall Space Flight Center, Alabama 35812.

\section{ABSTRACT}

This document is the Final Report of the Solar Hot Water System located at the Red Star Industrial Laundry,3333 Sabre Avenue, Fresno, California. The system was designed as an integrated wastewater heat. recovery and solar preheating system to supply a part of the hot water requirements. It was estimated that the natural gas demand for hot water heating could be reduced by 56 percent ( 44 percent heat reclamation and 12 percent solar). The systcm consioto of a 16,500 gallon tubeand-she11 wastewater heat recovery subsystem combined with a pass-through 6,528 square foot flat plate Ying Manufacturing Company Model SP4120 solar collector subsystem, a 12, 500 gallon fiber glass water storage tank subsystem, pumps, heat exchangers, controls, and associated plumbing. The design output of the solar subsystem is approximately. $2.6 \times 10^{9}$ BTU/year. Auxiliary energy is provided by a gas fired low pressure boiler servicing a 4,000 gallon service tank.

This project is part of the U.S. Department of Energy's Solar Demonstration Program with DOE sharing $\$ 184,841$ of the $\$ 260,693$ construction cost. The system was turned on in July, 1977, and acceptance tests completed in September, 1977. The demonstration period for this project ends September 2, 1982.

19. SECUAITY CLASSIF. (d thle roport) Unclassified
20. SECURITY CLASSIF. (OA ISL WEO) Unclassified
21. No. OF PALES

83
22. PRICE

NTIS 
THIS PAGE

\section{WAS INTENTIONALLY LEFT BLANK}




\section{TABLE OF CONTENTS}

SECTION NO.

PAGE NO.

1.0

System Description

1.1 Wastewater Heat Recovery Subsystem

1.2 Solar Subsystem

1.3 System Integration

1.4 Site and Building Description

2.0 Acceptance Test Plan 11

2.1 Acceptance Test Plan and Schedule 12

2.2 Test Results and Corrective Actions 27

3.0 Engineering Drawings Wiring and Piping Schematlcs . 28

4.0 Operation and Maintenance Instructions 33

4.1 Operational Modes 34

4.2 Control Logic and Temperature Ranges 39

4.3 System Start-Up \& Preventative Maintenance 44

5.0. Photographs 45

6.0 Performance Predictions and Kesults To-Date 48

6.1 Thermal Balance Analyses. 49

6.2 Computed Data for Period from March to May 1978

7.0 Major Problems $\quad 64$

$\begin{array}{lll}7.1 & \text { Solar Collector Selection } & 65\end{array}$

7.2 Structural Problems 66

7.3 Stagnation Conditions $\quad 66$

7.4. Dust Accretion 67

7.5 Alarm and Display Systems 67

7.6 Constant Flow Regulators 68

7.7 IBM Instrumentation and Performance Data 68

7.8 Program Management 68

8.0 Lessons Learned and Recommendations 69

$\begin{array}{lll}9.0 & \text { Certification } & 71\end{array}$

\section{APPENDICES}

A Instrumentation Sensor/J-Box Interconnection Tables 73

$\begin{array}{lll}\text { B List of Manufacturers } & 78\end{array}$

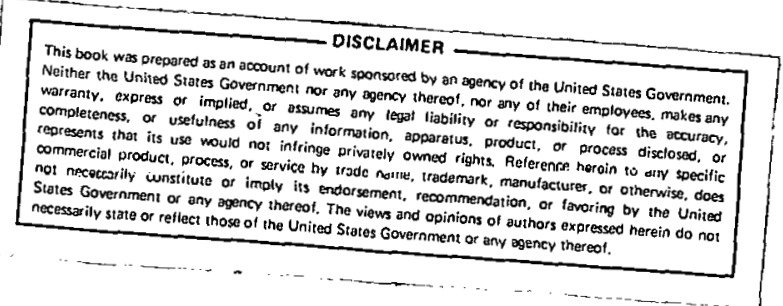


SECTION 1.0

SYSTEM DESCRIPTION 


\section{SECTION 1.0 INTRODUCTION \& SUMMARY}

In response to a request by Truman Temple and Associates in November 1975, ARATEX Services, Inc. (then Work Wear Corporation) agreed to participate in a response to a Phase 1 Program Opportunity Notice (PON-1) issued by the U.S. Department of Energy (DOE), then the Energy Research and Development Administration (ERDA). At that time it was decided that the Red Star Industrial Service Laundry at 3333 No. Sabre Avenue, Fresno, California would be an ideal site to demonstrate energy conservation through the use of an advanced wastewater heat recovery system combined with solar pre-heating of the incorning water. With a projected future hot water consumption of 60,000 gallons per day, the plant was considered to be representative of the typical medium sized industrial laundry facility. Other considerations in the site selection included:

- Proximity to a National Weather Service Station at the Airport, approximately 1 mile away, from which good meteorological data could be derived.

- Seasonal weather conditions which range from foggy, cloudy, freezing conditions in winter to very low humidity and summer temperatures exceeding $100^{\circ} \mathrm{F}$.

- A building constructed within the last 10 years, having a reasonably flat roof.

Following announcement of the award of a contract to the Work Wear Corporation in April 1976, it became apparent that Truman Temple and Associates lacked the facilities to produce the large number of flat-plate collectors required for this particular project. Subsequent negotiations with other solar collector contractors confirned the fact that it was going to be very difficult to find a contractor who could produce the required number of collectors in conformance with the specifications laid down, specifically with respect to the weight of the individual collectors. It was recognized, even at this early stage of the project, that roof loading was going to be a critical problem. Similar problems were encountered in obtaining performance data from most of the manufacturers. A further problem related to the inadequacy of the funding proposed for this project. Protracted negotiations with the Energy Research and Development Administration failed to achieve any resolution of this problem. Finally, the California State Energy Commission agreed to provide additional funding in the arnount of $\$ 17,000.00$ to the project. The Energy Research and Development Administration agreed to fund the project to a maximum of $\$ 165,000.00$. With this total of $\$ 1 \$ 2,000.00$, plus an estimated $\$ \$ 1,000.00$ to be contributed by the Contractor, it appeared that the project was viable. 
Meanwhile, in the interest of energy conservation, the Contractor had decided to go ahead with the iristallation of an advanced wastewater heat recovery system. Work was completed on this phase of the project in early 1976. Final system definition and selection of Ying Manufacturing Corporation as the supplier of the flat-plate collectors was not completed until late in 1976. In November 1976, one year after the submittal of the proposal, a joint venture team consisting of Ying Manufacturing Corporation of Gardena, California with Clark, Mechanical Inc. of Long Beach, California was selected for the installation of the solar system. Contracts were signed at that time. The solar system was to consist of 6,500 square feet of flat-plate collectors, with a 12,500 gallon storage tank integrated into the wastewater heat recovery system and auxiliary process hot water system at the facility. Theoretical performance data for the system is presented in Section 6.0 of this report. Following preliminary and final design reviews with NASA personnel, fabrication of the solar system was commenced in December 1976. At that time, work was also begun on site preparation, which included resurfacing of the roof to accept the solar array. Work proceeded smoothly on the manufacture of the solar panels through March 1977, when the panels and storage tank were delivered to the site. Installation and integration of the system and work was essentially completed in July 1977. The installation of IBM instrumentation, for which a separate contract was awarded, led to a delay of between two and three weeks in completion and start-up of the system. Subsequently, it has been found necessary to make additional modifications to the instrumentation, which were not completed until August 1978. Accurate performance data on the system has only recently become available (September 1978).

The system was declared operational at the end. of July 1977, and was formally dedicated by California's Governor Brown on September 23, 1977. The system is, at this time, fully operational and has been since the end of July 1977, although some minor storm damage was experienced in January 1978. In addition to the need to repair the storm damge, which included breakage or partial separation of several of the Lexan covers and some damage to the absorptive coating, there is a need to study the phenomena, believed to be electro-static, which has resulted in excessive accuinulation of dust in the Lexan covers. Ninety (90) of the solar collector pancls have been resurfaced and reglazed, using Tedlar. It is anticipated that the remaining fifty (50) panels will eventually be re-worked, if DOE funding is made available to the project. 


\section{SECTION 1.1 WASTEIVATER HEAT RECOVERY SUBSYSTEN}

This subsystem, responsible for between $35 \%$ and $40 \%$ reduction in energy used for process water heating, consists of the following elements:

- Ludell insulated tube-and-shell heat exchanger (Three $8^{\prime \prime}$ dia. $\times 20^{\prime}$ sections)

- Hydr-O-Matic wastewater pump (4") with 5 H.P. motor.

- Mercoid low-level cut-off switch and high level override.

- Dezurik (or equivalent) butterfly valves for flow regulation of cold water and wastewater.

- DeZurik 4-port 2-way backflush valve, with pneumatic actuator and timer.

- Control circuits associaled with demand control by the solar subsystem or the auxiliary ener gy subsystem.

$\therefore \quad$ In the "NORMAL" mode of operation, the wastewater pump serves to trainsfer energy from the wastewater storage pit (16,000 galloris maximum capdcily) through the tubc...and. shell heat exchanger to the incoming city water, which has been sof tened by ion exchange.

The control circuits and flow rates are set to transfer energy on a near-continuous basis from wastewater to incoming water during the working day. This ensures maximum effeciency of heat transfer; while satisfying the basic requirement for optimum system $\mathrm{U}$-value (Btu/hr/ft${ }^{2} /{ }^{\circ} \mathrm{F}$.). The "Approach Temperature" or temperature differential between wastewater inlet temperature and freshwater outlct temperature (typically between $3^{\circ} \mathrm{F}$. and $8^{\circ} \mathrm{F}$.), is a measure of the efficiency of heat transfer.* The system was designed to improve the figure-of-merit for hot water supplied to the plant from 78.3 gallons of hot water/therm to 138.5 gallons/therm.

During the "WEEK-EN[)" mode (Ste scetion 1.2, bclow) the heat exchanger and wastewater pump - with associated change-over valves - are used to transfer excess heat from the solar storage tank at temperatures above $190^{\circ} \mathrm{F}$. to pre-heat wastewater for a "Hot Start" at the end of a week-end or holiday. Unfortunately, operational problems not directly associated with this subsystem or the solar subsystem have so far precluded full utilization of this mode: In brief, the necessity for frequent pump-out of the wastewater pit at weekends to prevent excessive build-up of sludge and pollutants has prevented the full capabilitics of the week-end mode from being realized. Alternate sludge removal procedures are currently being investigated, together with a timed drain/re-fill system.

* Older, less efficient heat exchangers, if used at all, may have approach temperatures of $10 \mathrm{~F}$. to $2 \mathrm{~S}^{\mathrm{F}} \mathrm{F}$., being considerably less eflicient. 


\section{SECTION 1.2 SOLAR SUBSYSTEM}

This subsystem, designed for a nominal input to the hot water supply system of $2 \times 10^{9}$ BTU/year, is designed to derive the maximum benefit from the total insolation at the site through the use of two alternate modes of operation; the "NORMAL" mode and a "WEEKEND" mode of operation. (See Figure $1-1$ )

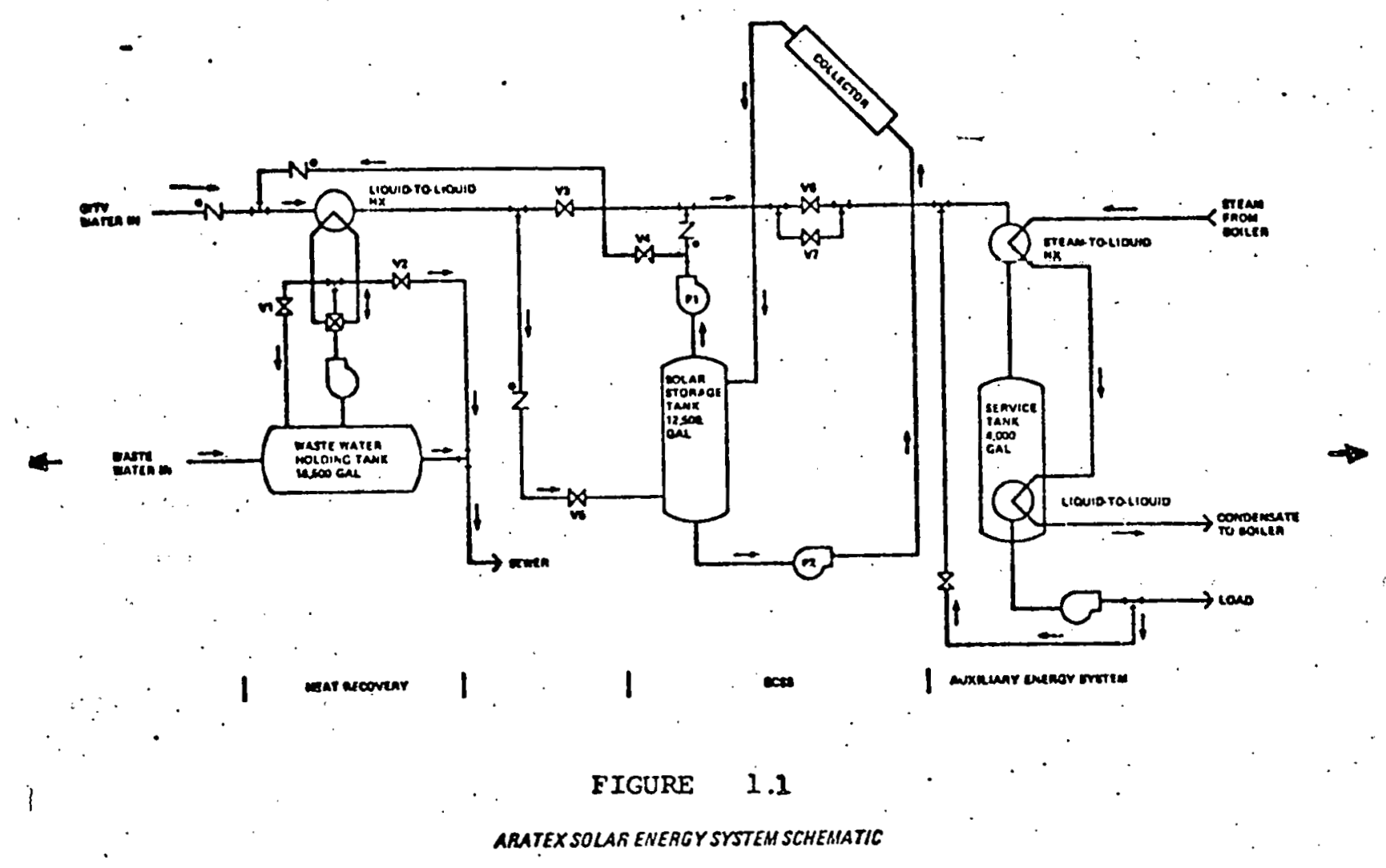

During the normal mode of operation, the sequence of events is as follows:

Hot water demand on the auxiliary hot water tank activates a level control to open $V-6$, allowing preheated water from the solar storage tank to be transferred by $P-1$ to the auxiliary storage tank. Water withdrawn from the solar storage tank is replaced when a level control in the solar storage tank opens V-5, allowing fresh water to flow into the storage tank via the wastewater heat recovery exchanger through $V-5$. In the event that there is an unusually heavy demand fo: hot water from the auxiliary storage tank, a second level control on this tank activates $V-3$, thereby providing additional flow from the wastewater heat exchanger directly through the large diameter by-pass valve $V-7$ to the auxiliary storage tank. Under these conditions, fresh water is being supplied both from the solar storage tank by $\mathrm{P}-1$ and from the wastewater heat exchanger directly through $\mathrm{V}-3$, passing to the auxiliary storage tank through $V-6$ and $V-7$, both of which are open at this time. 
Provided that there is sufficient wastewater in the pit, the wastewater circulating pump will be activated whenever there is a demand for fresh water by the solar storage tank; indicated by the opening of $\mathrm{V}-5$. A timer is activated whenever the wastewater pump is operating to enable the wastewater heat exchanger to be back-flushed. Identical timers are used to initiate or discontinue circulation of water through the solar collectors after pre-set delays. Solar pumps P2-A and P2-B are activated by these timers, which serve to minimize circulation of water through the solar collectors due to intermittent insolation caused by clouds and spurious start-up at the beginning of the day. A solar temperature control unit inhibits operation of the solar collector loop when the temperaiure differential between the collectors and the solar storage tank temperature is less than $4.5^{\circ} \mathrm{F}$. Similarily, this same unit shuts off P2-A and P2-B, allowing the solar collectors to drain back to the solar storagie tank when the temperature differential between the solar collectors and the storage tank is less than $1.5^{\circ} \mathrm{F}$.

In the "WEEK-END" mode of operation, activated by a manually conlrulled switch on the control panel, the solar collector loop and P2-A/P2-B operate under automatic control of the solar temperature control unit. In this mode of operation, neither cold water nor compressed air are normally available for use by the subsystems. Consequently, all valves and controls in this mode have to be electrically operated or make use of spring-return for actuation. Excluding only the solar collector circulation loop, all controls and pumps are normally quiescent until the temperature of the water in the solar storage tank reaches $170^{\circ} \mathrm{F}$.

When the solar storage tank temperatures exceed $170^{\circ} \mathrm{F}$, water from the solar storage tank is circulated by $\mathrm{P}-1$ through $\mathrm{V}-4$ and the wastewater heat exchanger back to the solar storage tank via V-5. Simultaneously, the wastewater pump P-3 is activated to circulate wastewater through the heat recovery unit, thereby transferring heat from the solar storage tank to the wastewater pit. This mode of operation continues until the temperature of the solar storage tank drops to $160^{\circ} \mathrm{F}$, at which point the recirculating loop is disabled by the same temperature controller previously used for initiation of the recirculation cycle. It should be noted here that all temperature and Jevel controls have a differential band over which they operate. This feature contributed significantly' to the simplification of the control system for this project.

In the unlikely event that the tempcrature in the solur storage tank reaches $190^{\circ} \mathrm{F}$., a high level temperature collector disables the solar collector circulating loop allowing the collectors to drain back into the storage tank. This condition obtains only if the level in the 
wastewater pit is too low to allow the wastewater pump P 3 to be activated, thereby inhibiting hoat transfer to the wastewater pit. To mitigate this problem, a.timed drain and re-fill system is being considered, in order to lower the initial storage tank temperature from $115^{\circ} \mathrm{F}$. to $75^{\circ} \mathrm{F}$. at week-end.

For diagnostic purposes, supplemented by alarm and display circuits discussed earlier, all pumps can be operated manually from the control panel. Alarm circuits and the display board allow for near instantaneous diagnosis of any major system component failure.

\section{SECTION 1.3 - SYSTEM INTEGRATION}

The tie-in of the solar subsystem to the existing wastewater heat recovery subsystem and the auxiliary heating subsystem on a non-interference basis presented a few problems for the following reasons:

- The cold water tank, solar tank and auxiliary tank were not pressurized, i.e. they were open to atmosphere. They could, therefore, be by-passed at any time during system integration.

- An adequate number of by-pass valves had been provided, prior to installation of the solar subsystem, to allow for easy integration of all hydraulic connections.

- Extensive on-site instrumentation was provided - at no expense to the contract including a manometer, pressure and temperature gauges, to allow all elements of the solar subsystem to be calibrated and tested with no interference to plant operations.

- The single electrical tie-in to the auxiliary subsystem, involving a change of operating voltage on valves $V-6$ and $V-7$ by the replacement of solenoids and rewiring in the solar control panel, was effected in two hours following plant shut-down in the evening.

System integration, test and calibration was completed in two days, with less than 30 hours man-hours of effort.

It cannot be too strongly emphasized that provision of adequate on-site instrumentation with analog read-out is essential to smooth integration of large systems. The failure of D.O.E. to provide an on-site monitor (OSM) to the project could have seriously jeopardized the test and integration phase of the project, if adequate instrumentation had not been provided by the sub-contractors at their own expense. 


\section{SECTION 1.4 SITE AND BUILDING DESCRIPTION}

The site and building description has been adequately covered in earlier documentation.

Summary information presented in this report was prepared by Planning Research Corporation Energy Analysis Company, and is reproduced here only for the sake of completeness of this report.

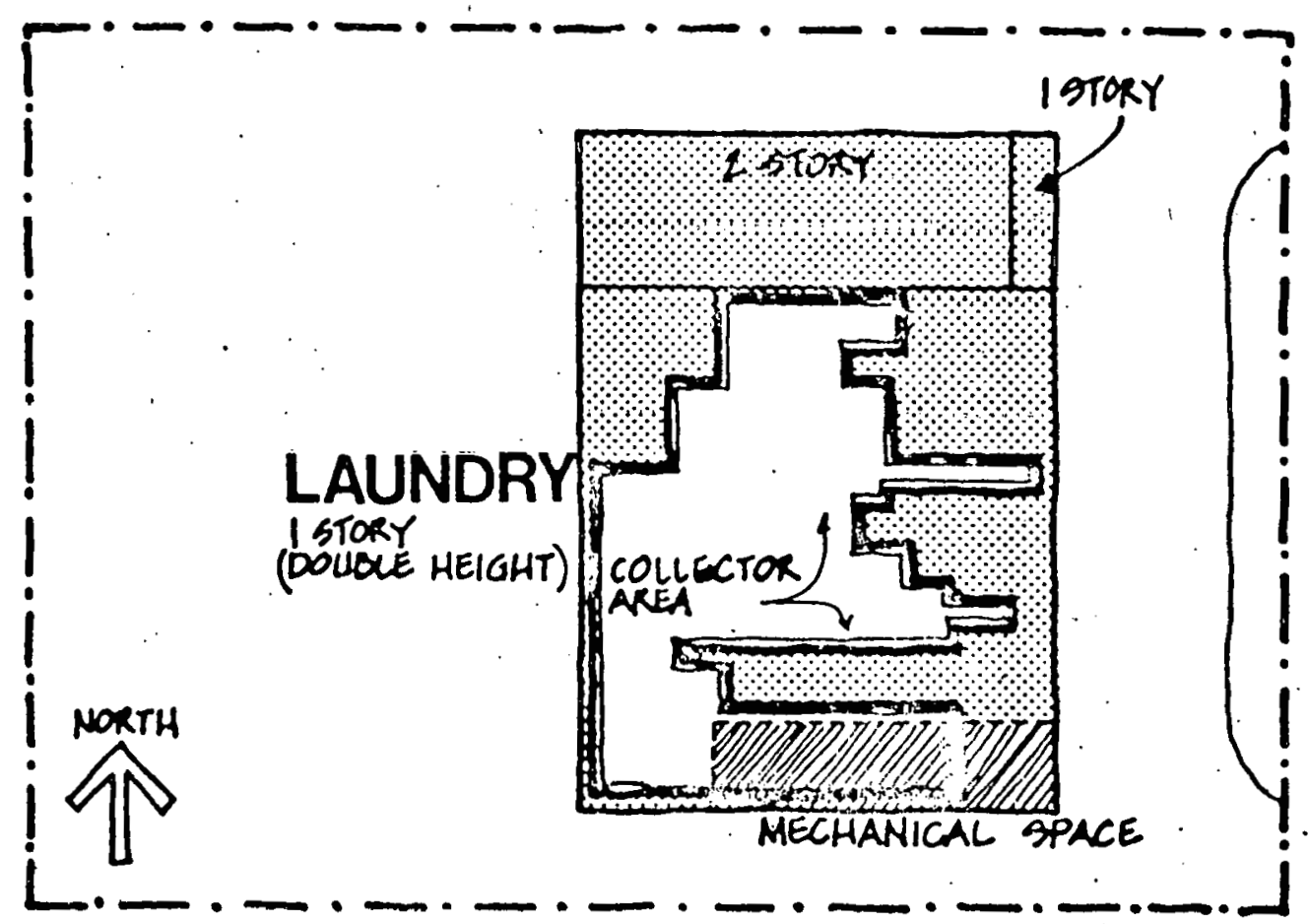

FIGURE III-1

Site Plan

Site Description

- Special topographic and climatic conditions - NONE

- Area topographic description - NONE

- Latitude $-36.75^{\circ} \mathrm{N}$

- Annual degree days $\left(65^{\circ} \mathrm{F}\right.$ base)

- Heating - 2699

- Cooling - 1437

- Data location - Fresno, California

- Data source - "Local Climatological Data, Annual Summaries for 1976", U.S. Department of Commerce, National Oceanic and Atmospheric Adininistration. 
- Average horizontal insolation

- January - 1750 BTU/FT' ${ }^{2}$ D $A Y$

- July - 2228 BTU/FT ${ }^{2}-$ DAY

- Data location - Fresno, California

- Site topographic description - FLAT

- Shading - NONE

\section{Building Description}

- Occupancy-- INDUSTRIAL LAUNDRY

- Total building area - 32,500 $\mathrm{FT}^{2}$

- Solar conditioned space - NONE

- Number of stories - one story, approximately 20 FT high in laundry area, and about $20 \%$ of total floor area has a second story (above office space).

- Roof slope - FLAT

- Special features - Combined solar hot water and wastewater heat recovery system - large single collector arca.

\section{Structure}

- Walls

- Frame - CONCRETE Tilt-up panels

- Exterior finish - PAINTED CONCRETE

- Insulation - NONE

- Interior finish - PAINTED CONCRETE

- Windows - NONE

- Doors - About $60 \%$ of rear (west) wall of laundry section opens with motorized overhead roll-tip doors (12 FT x $14 \mathrm{FT})$, approximately $1,000 \mathrm{FT}^{2}$ overall 


\section{- Roof}

- Frame - STEEL BEAMS, METAL JOISTS, CORRUGATED METAL ROOFING

- Exterior finish - 3 LAYERS BUILT-UP ROOF WITH GRAVEL

- Insulation - R-8, 2 IN OF RIGID INSULATION

- Interior finish - PAINT

- Roofing protection - Additional strip of rolled roofing laid between collectors.

- Floor - CONCRETE SLAB ON GRADE 
SECTION 2.0

ACCEPTANCE TEST PLAN 


\section{SECTION 2.0 GENERAL}

Following the Final Design Review with NASA personnel, an Acceptance Test Plan was drawn up and approved by NASA. The Acceptance Test Plan Schedule and the Acceptance Test Plan Reports follow in Section 2.1 of this report. It should be pointed out that in dealing with commercial contractors, it is difficult to follow the format and procedures normally followed on government contracts. Commercial contractors are, in general, not familiar with government procedures; nor does the funding on these demonstration projects allow for the formal procedures to be followed. On this project in particular, shortage of funds and personnel limited the usefulness of the Acceptance Test Plan as a configuration management tool.

\section{SECTION 2.1 ACCEPTANCE TEST PLAN AND SCHEDULE}

It should be noted that Item 5.0 of the Acceptance Test Plan was not documented by the Project Manager, since the tasks under Item 5.0 were, theoretically, strictly super visory under the jurisdiction of IBM. However, it should be further noted that funding limitations and the exigencies of the program were such that much of the electrical interfacing between the sensors and the SDAS were performed personally by the Project Manager and the Plant Engineer at no cost to the project. 
2.1 ACCEPTANCE TEST P:AN (ATP)

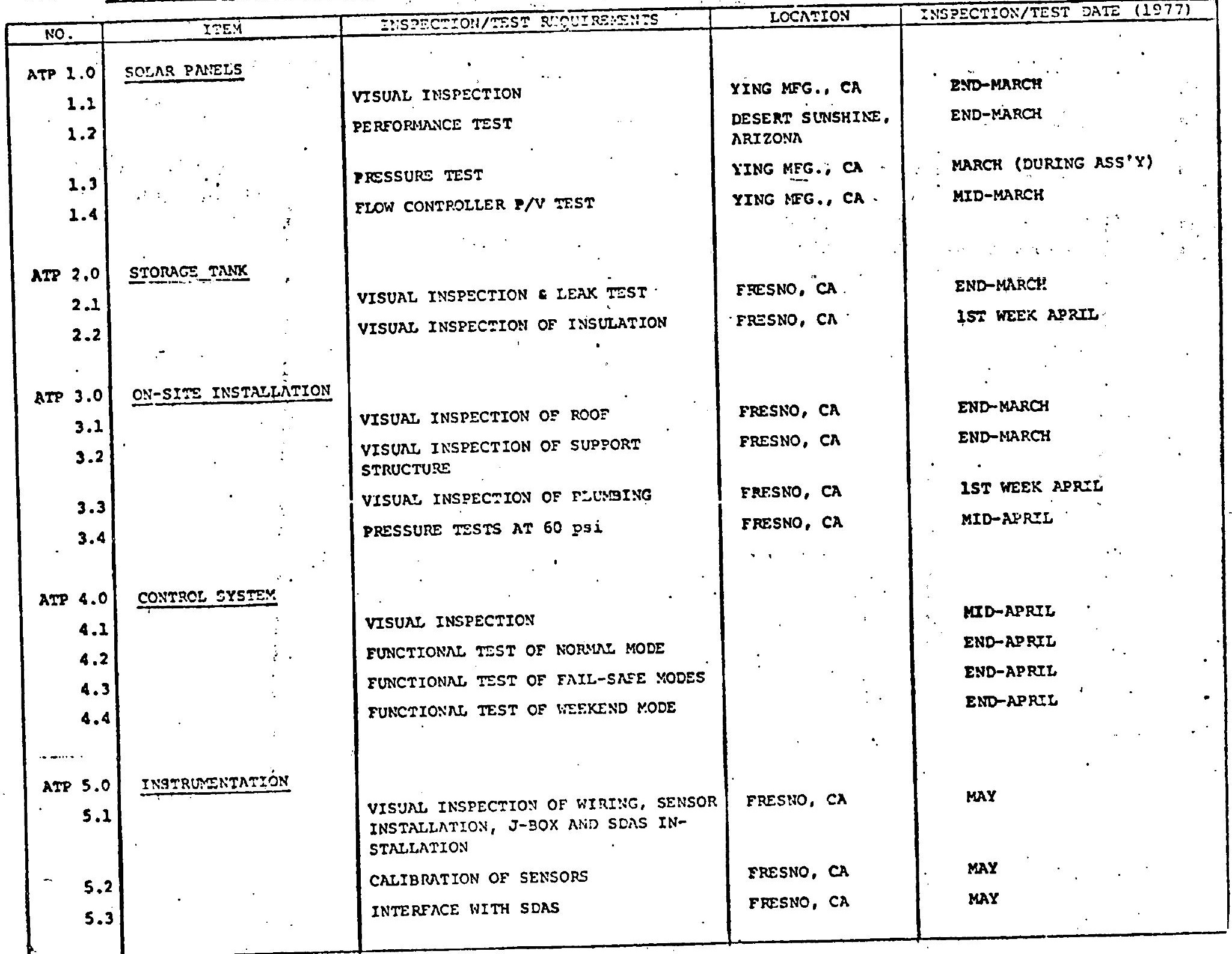


ACCEPTANCE TEST OF THE SOLAR HOT WATER HEATING DEMONSTRATION PROJECT (INDUSTRIAL LAUNDKY) AT

RED STAR INDUSTRIAL SERVICE

- 3333 SABRE AVENLE, FRESNO, CA

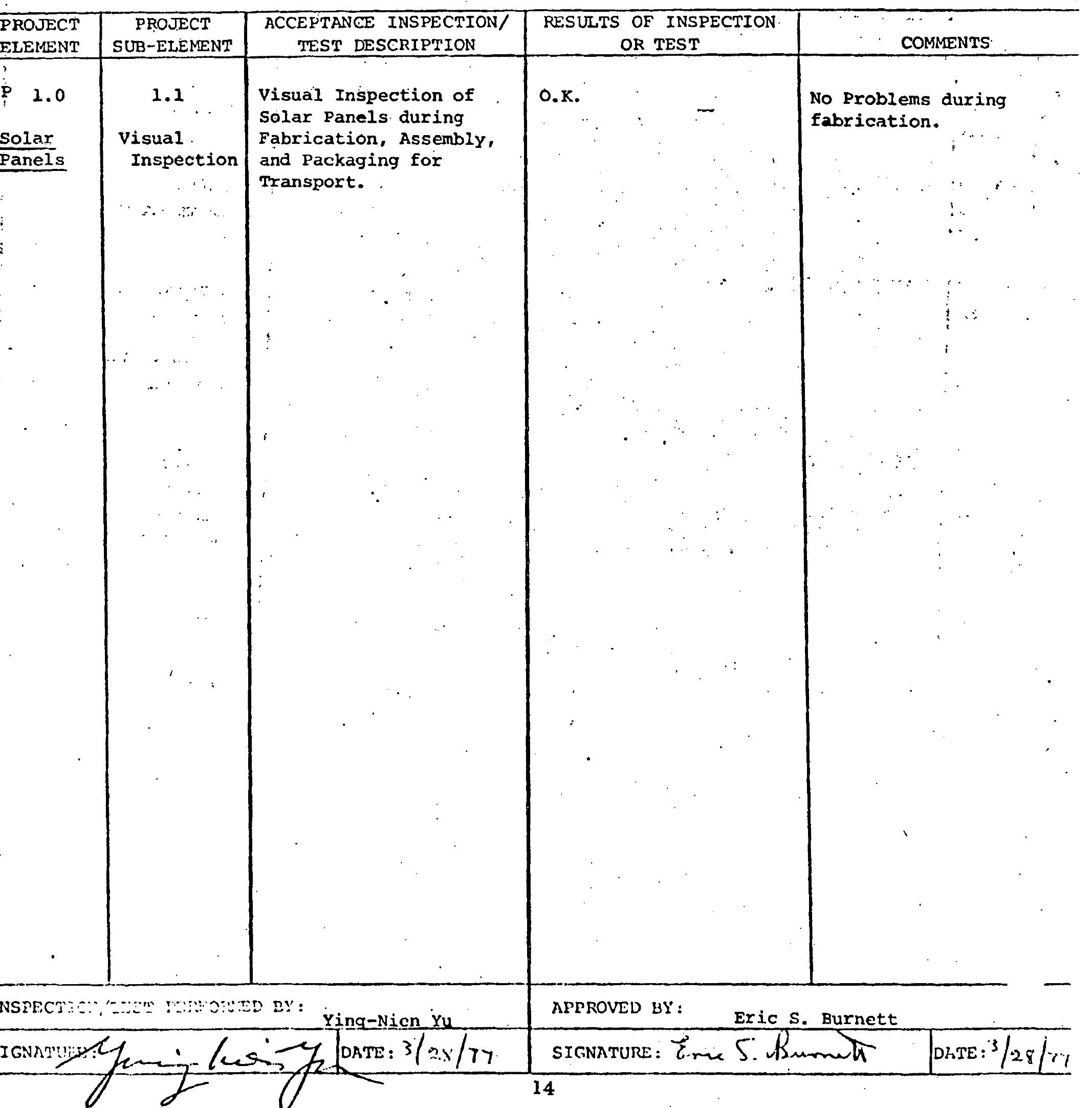


$\frac{\text { SECTION } 2.1 .1}{(\text { Sheet } 2 \text { of } 13)}$

ACCEPTANCE TEST OF THE SOLAR HOT WATER HEATING DEMONSTRATION PROJECT (INDUSTRIAL LAUNDRY) AT.

RED STAR INDUSTRIAL SERVICE

$\therefore \quad 3333$ SABRE AVENUE, $\because$ FRESNO, CA

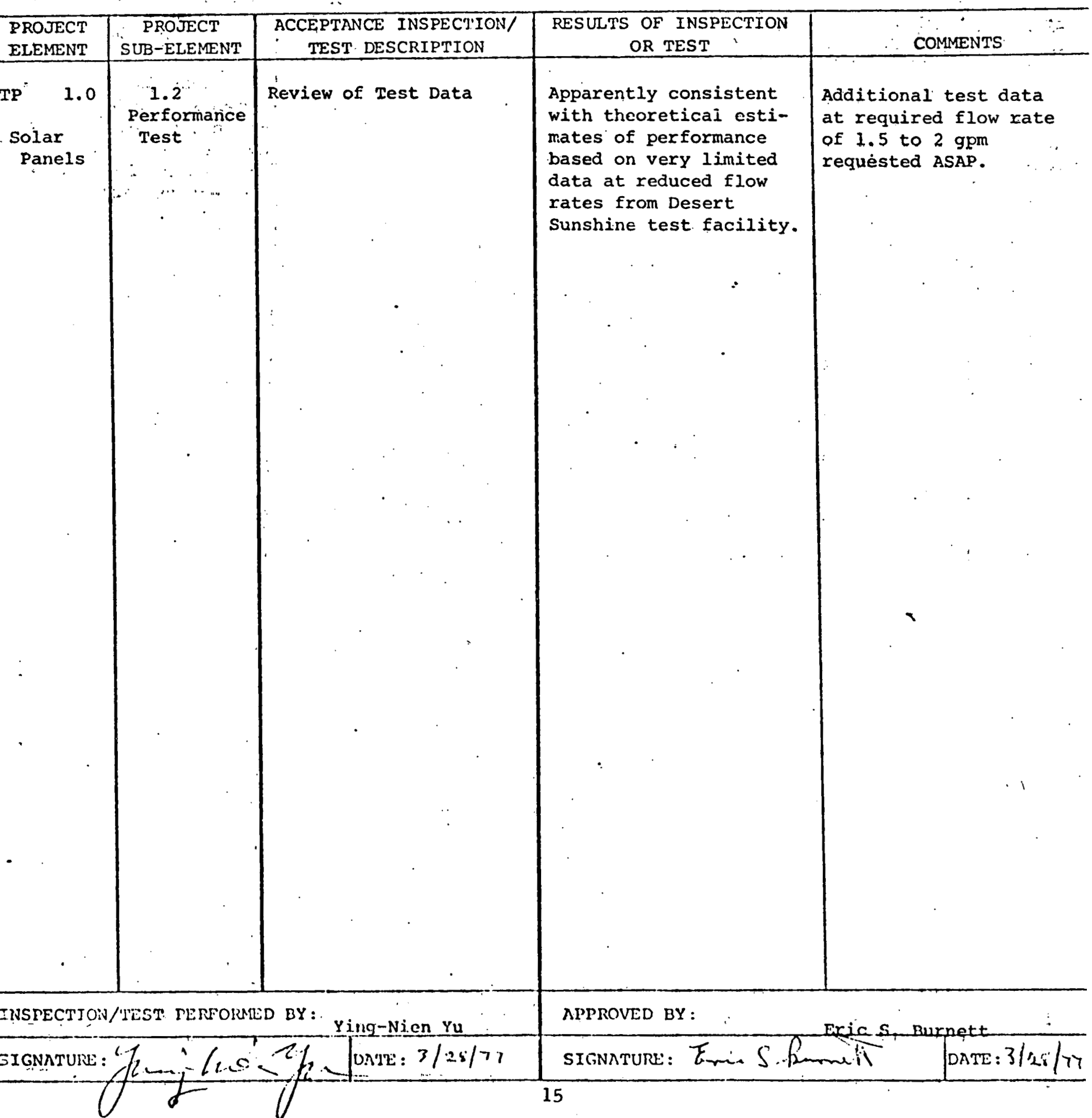


$\frac{\text { SECTION } 2 \cdot 1 \cdot 1}{(\text { Sheet } 3 \text { of } 13)}$

ACCEPTANCE TEST OF THE SOLAR HOT WATER HEATING DEMONSTRATION PROJEC' (INDUSTRIAL LAUNDRY) AT RED STAR INDUSTRIAL SERVICE

3333 SABRE AVENUE, FRESNO, CA

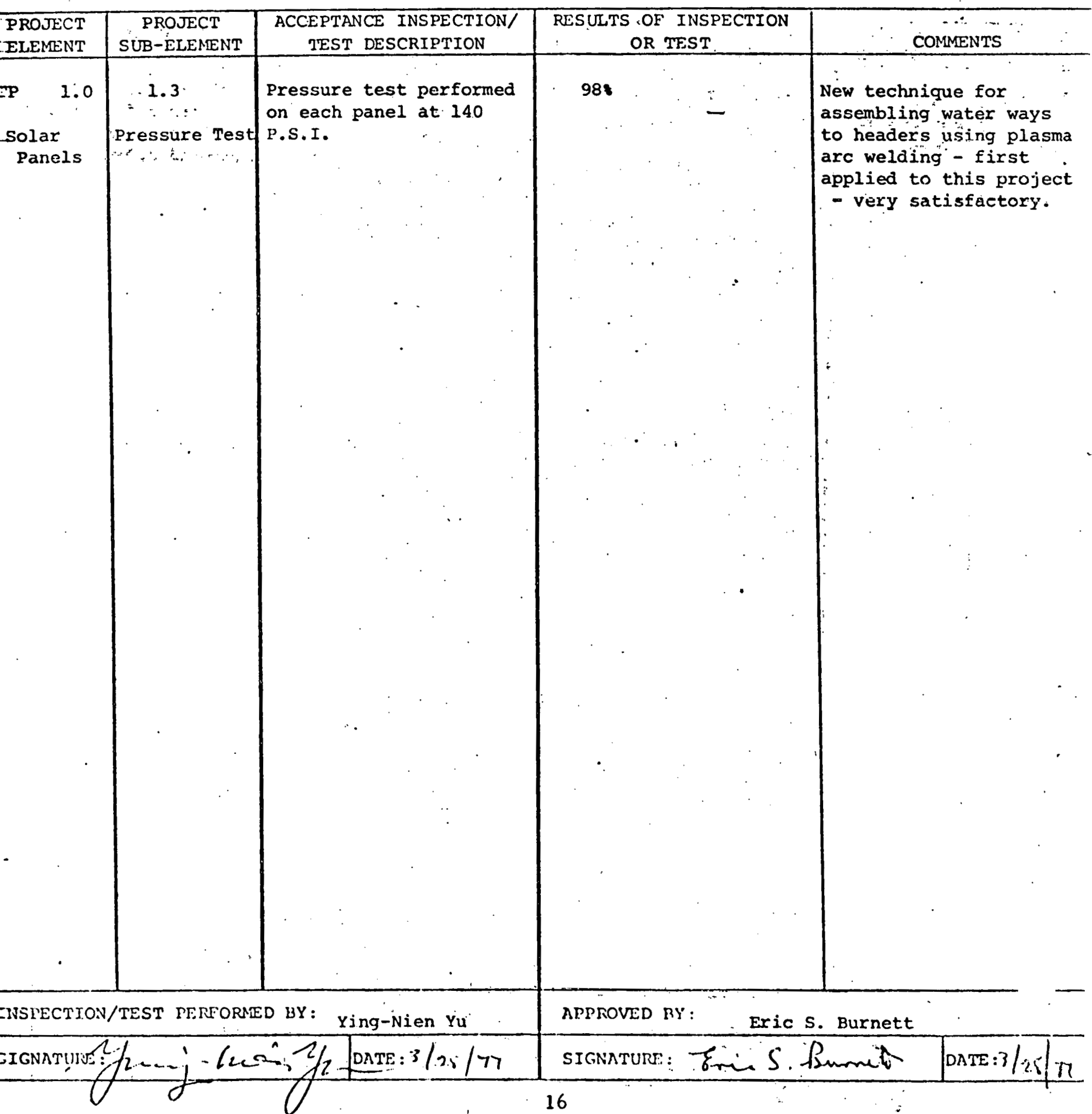


ACCEPTANCE TEST OF THE SOLAR HOT WATER HEATING

DEMONSTRATION PROJECT (INIUSTRIAL LAUNDRY). AT

RED STAR INDUSTRIAL SERVICE

- 3333 SABRE AVENUE, FRESNO, CA

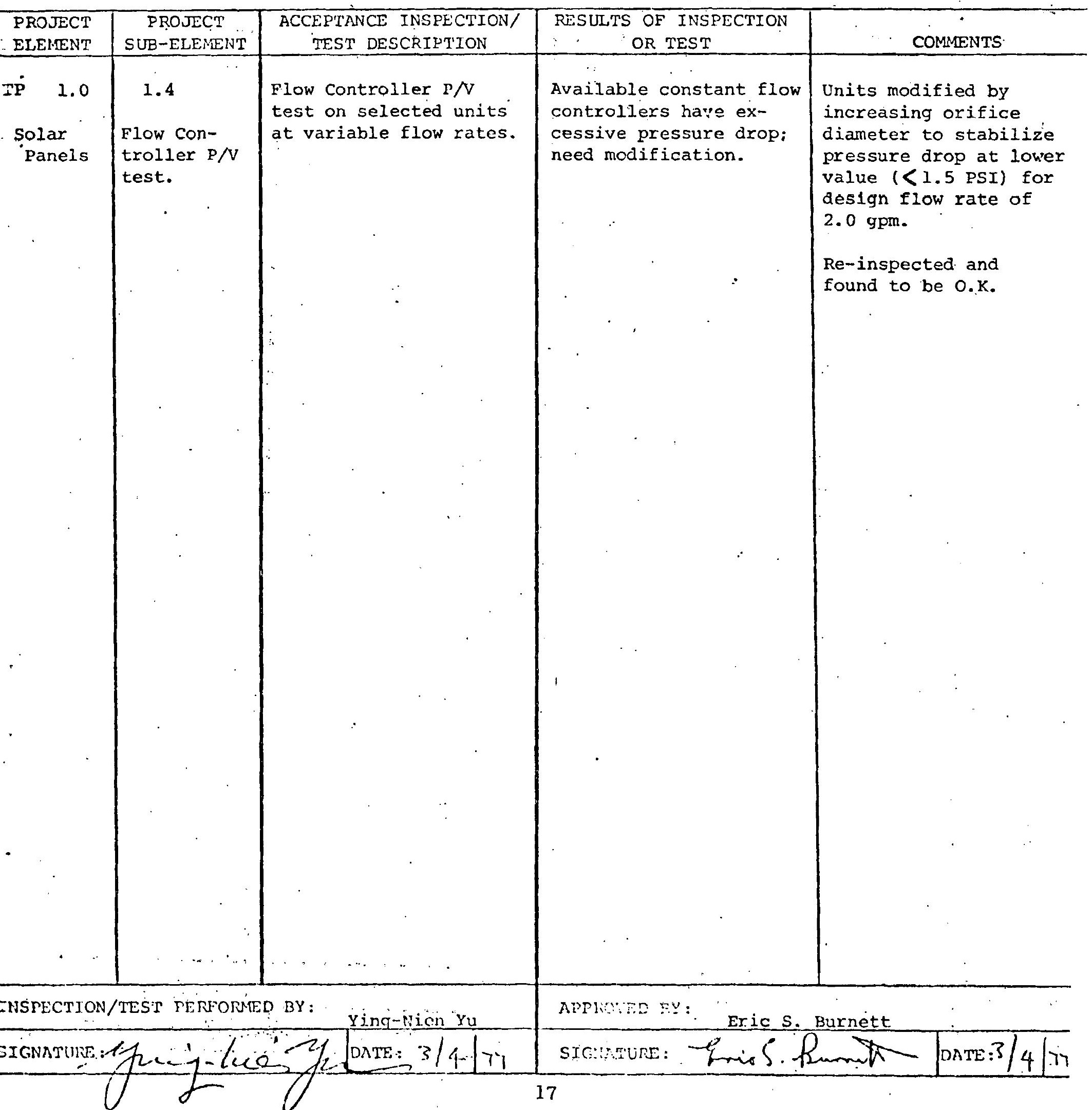


$\frac{\text { SECTION } 2.1 .1}{(\text { Sheet } 5 \text { of } 13)}$

ACCEPTANCE TEST OF THE SOLAR HOT WATER HEATING DEMONSTRATION PROJECT (INDUSTRIAL LAUNDRY) AT RED STAR INDUSTRIAL SERVICE - 3333 SABRE AVENUE, FRESNO, CA

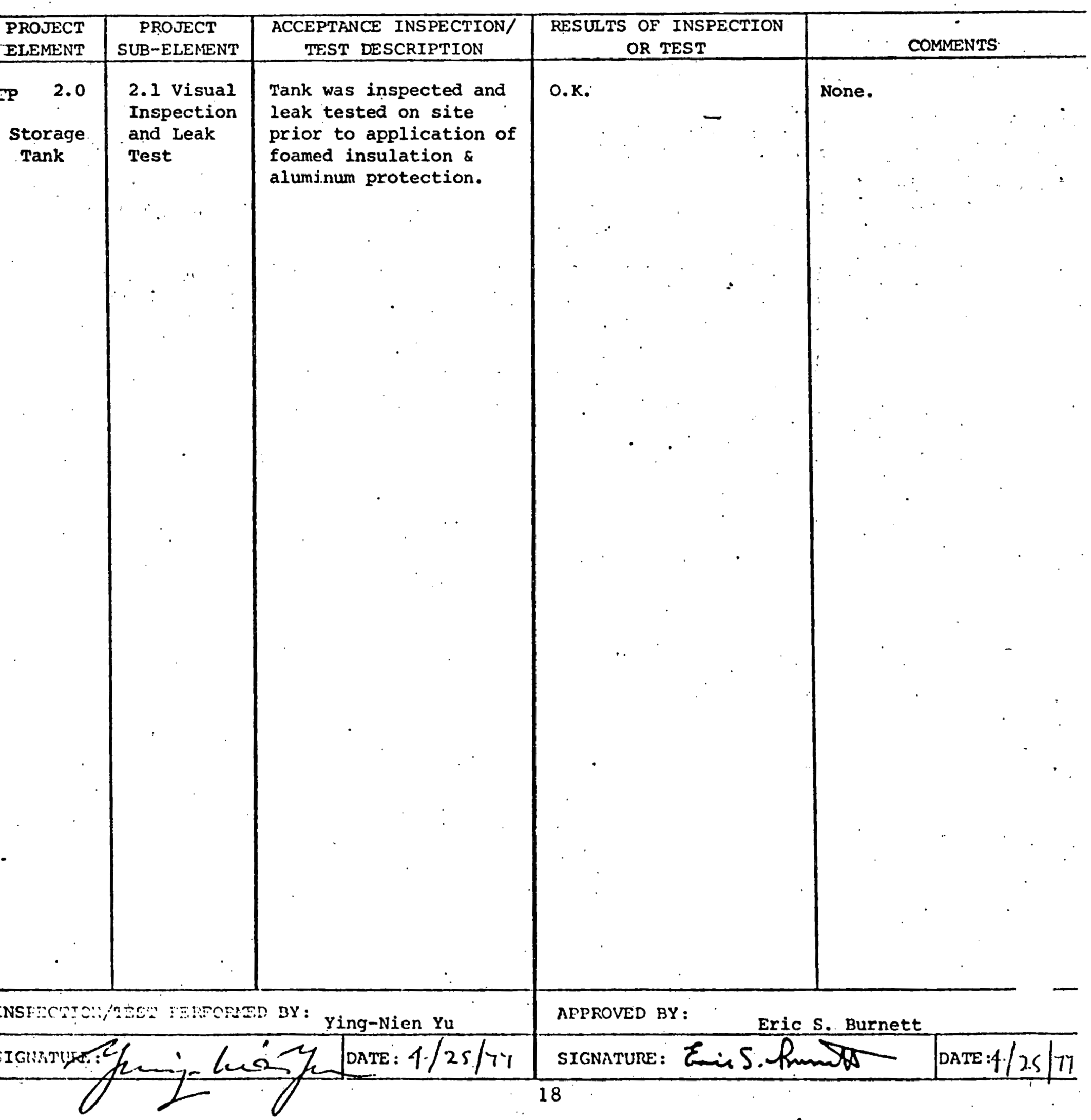


$\frac{\text { SECTION } 2 \cdot 1 \cdot 1}{(\text { Sheet } 6 \text { OI. } 13)}$

ACCEPTANCE TEST OF THE SOLAR HOT WATER HEATING DEMONSTRATION PROJECT (INDUSTRIAL LAUNDRY) AT RED STAR INDUSTRIAL SERVICE

3333. SABRE AVENUE, FRESNO, CA

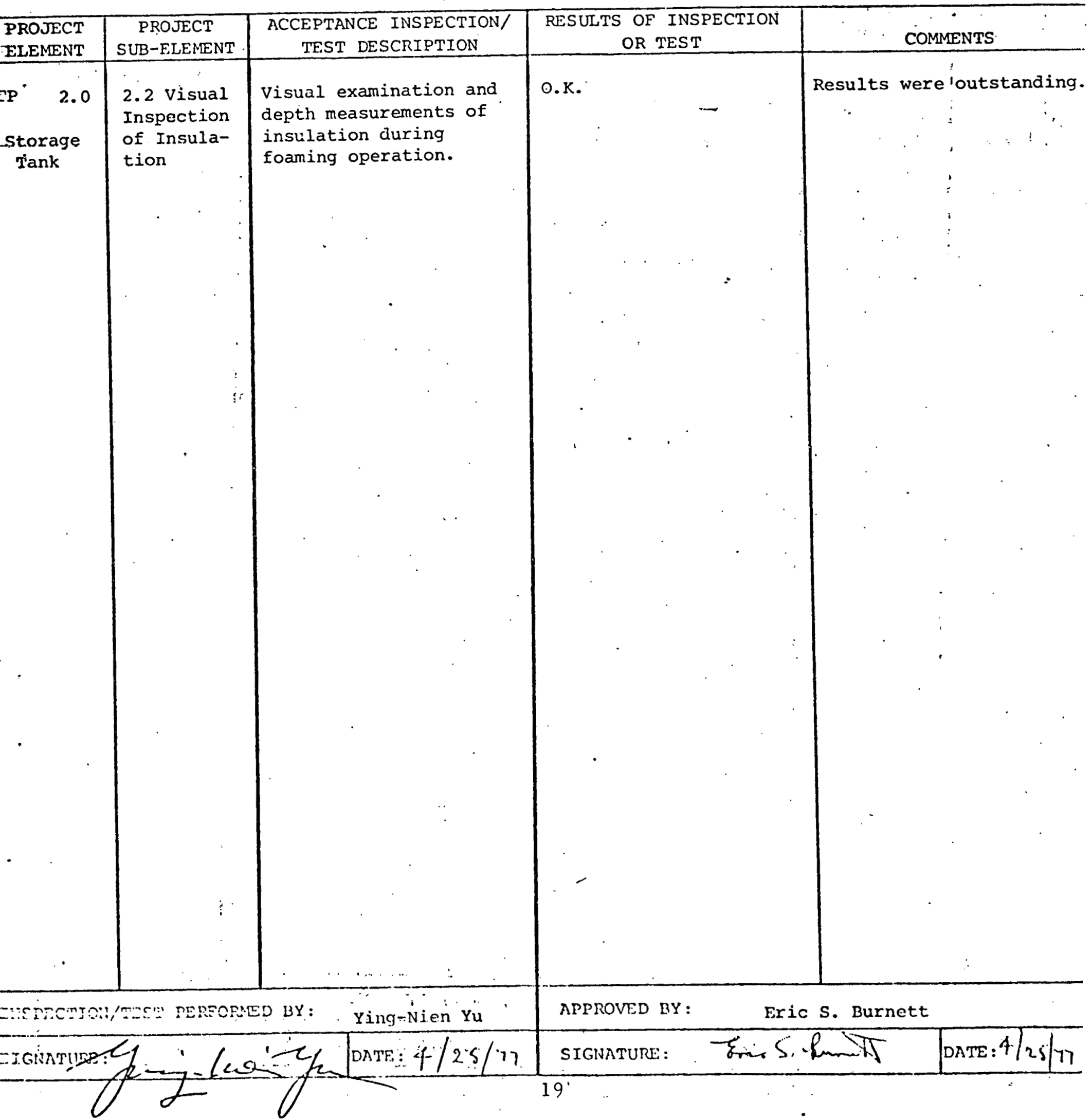


ACCEPTANCE TEST OF THE SOLAR HOT WATER HEATING

DEMONSTRATION PROJECT (INDUSTRIAL LAUNDRY). AT

RED STAR INDUSTRIAL SERVICE

- 3333 SABRE AVENUE, FRESNO, CA

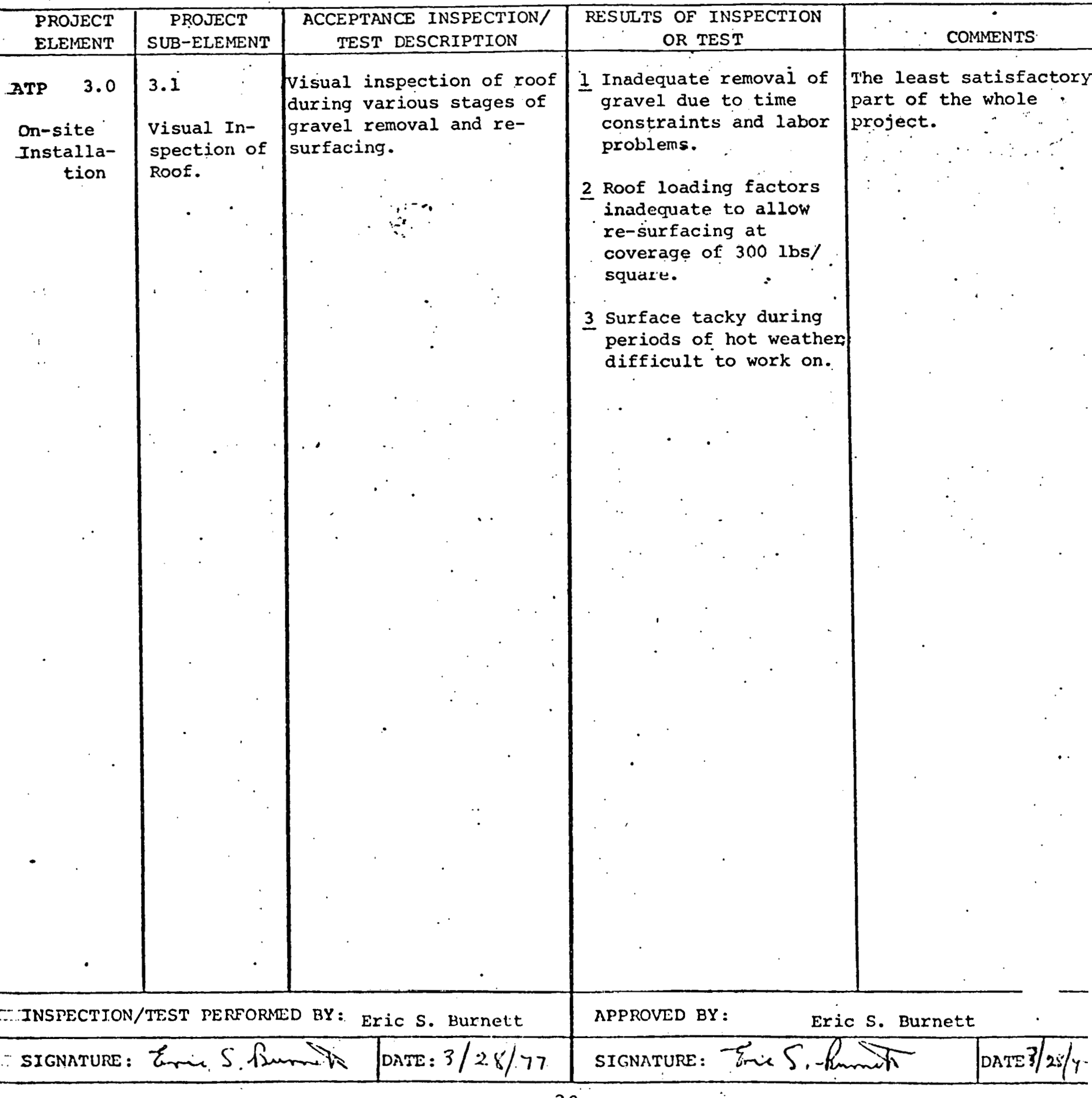


ACCEPTANCE TEST OF THE SOLAR HOT WATER - HEATING DEMONSTRATION PROJECT (INDUSTRIAL LAUNDRY) AT

RED. STAR INDUSTRIAL SERVICE

- 3333. SABRE AVENUe, fRESNo, Ca

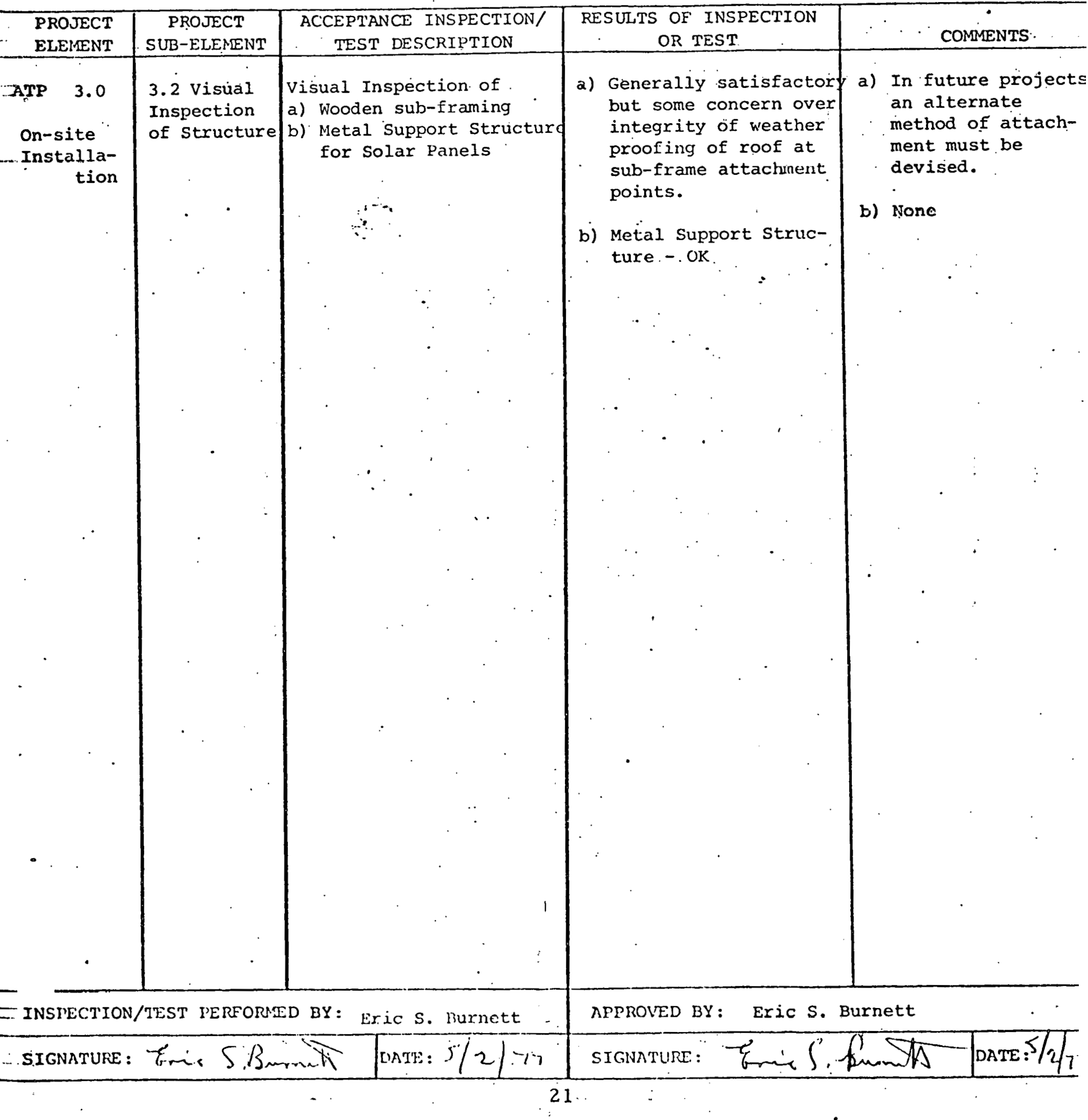




$$
\frac{\text { SECTION } 2.1 .1}{\left(\frac{1}{\text { Sheet } 9 \operatorname{cf} 13}\right)}
$$

ACCEPTANCE TEST OF THE SOLAR HOT WATER -HEATING DEMONSTRATION PROJECT (INDUSTRIAL LAUNDRY) AT RED STAR INDUSTRIAL SERVICE

- 3333 SABRE AVENUE, FRESNO, CA

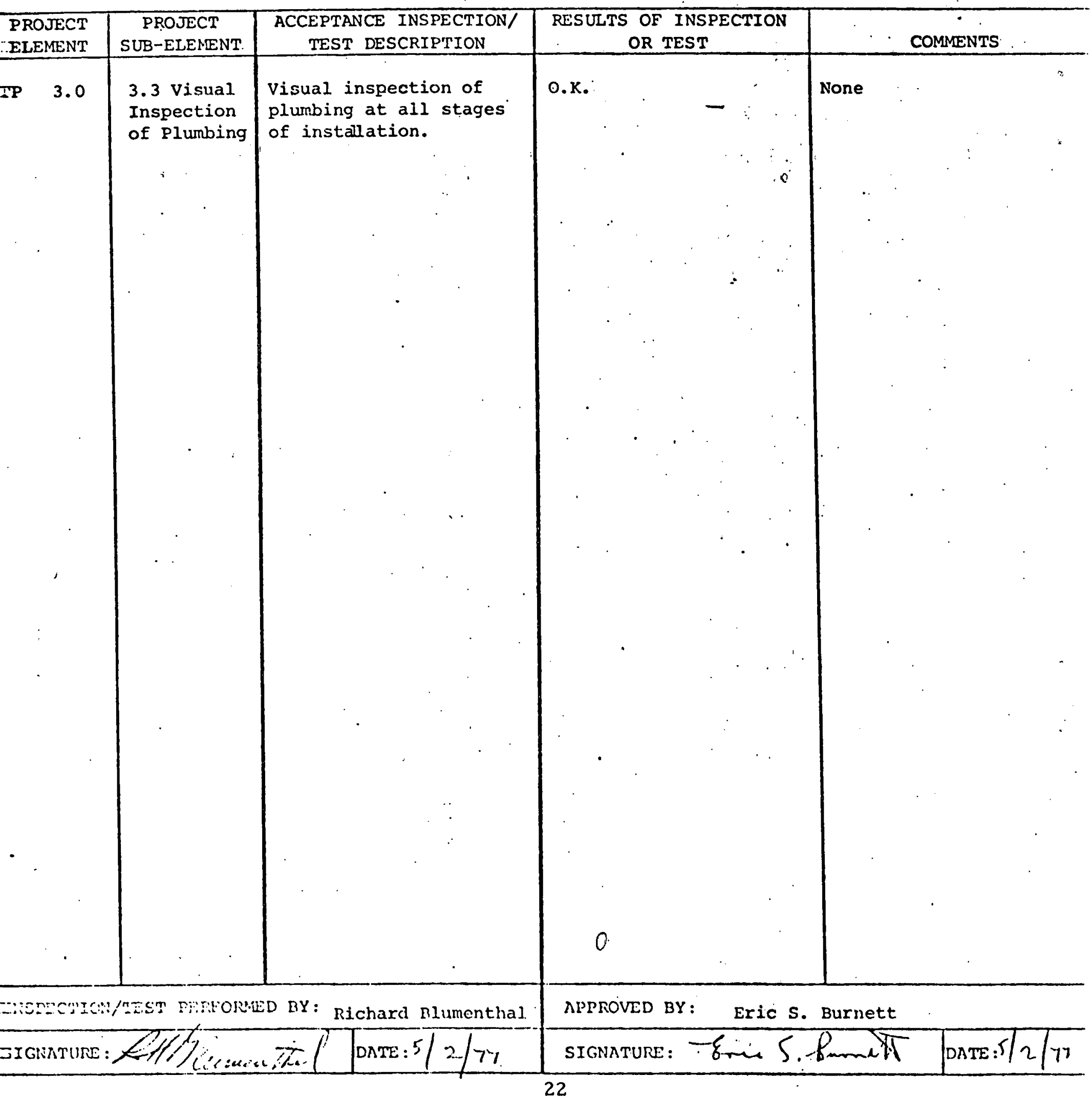


SECTION 2.1 .1

(Sheet 10 of 13 )

ACCEPTANCE TEST OF THE SOLAR HOT WATER HEATING DEMONSTRATION PROJECT (INDUSTRIAL LAUNDRY)"AT RED STAR INDUSTRIAL SERVICE

- 3333 SABRE AVENUE, FRESNO, CA

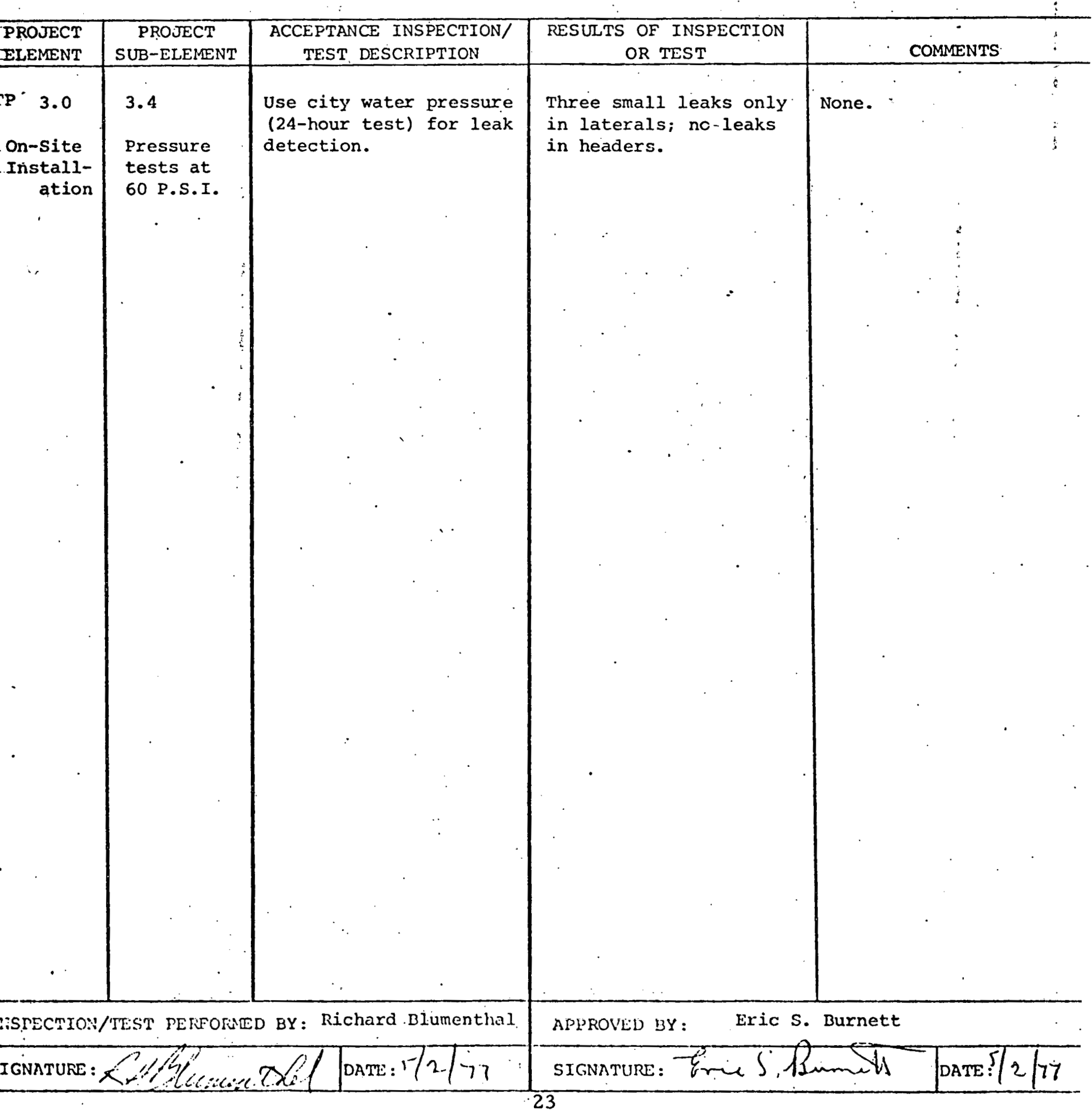


ACCEPTANCE TEST OF THE SOLAR HOT WATER HEATING DEMONSTRATION PROJECT (INDUSTRIAL LAUNDRY) AT

RED STAR INDUSTRIAL SERVICE

- 3333 SABRE AVENUE, FRESNO, CA

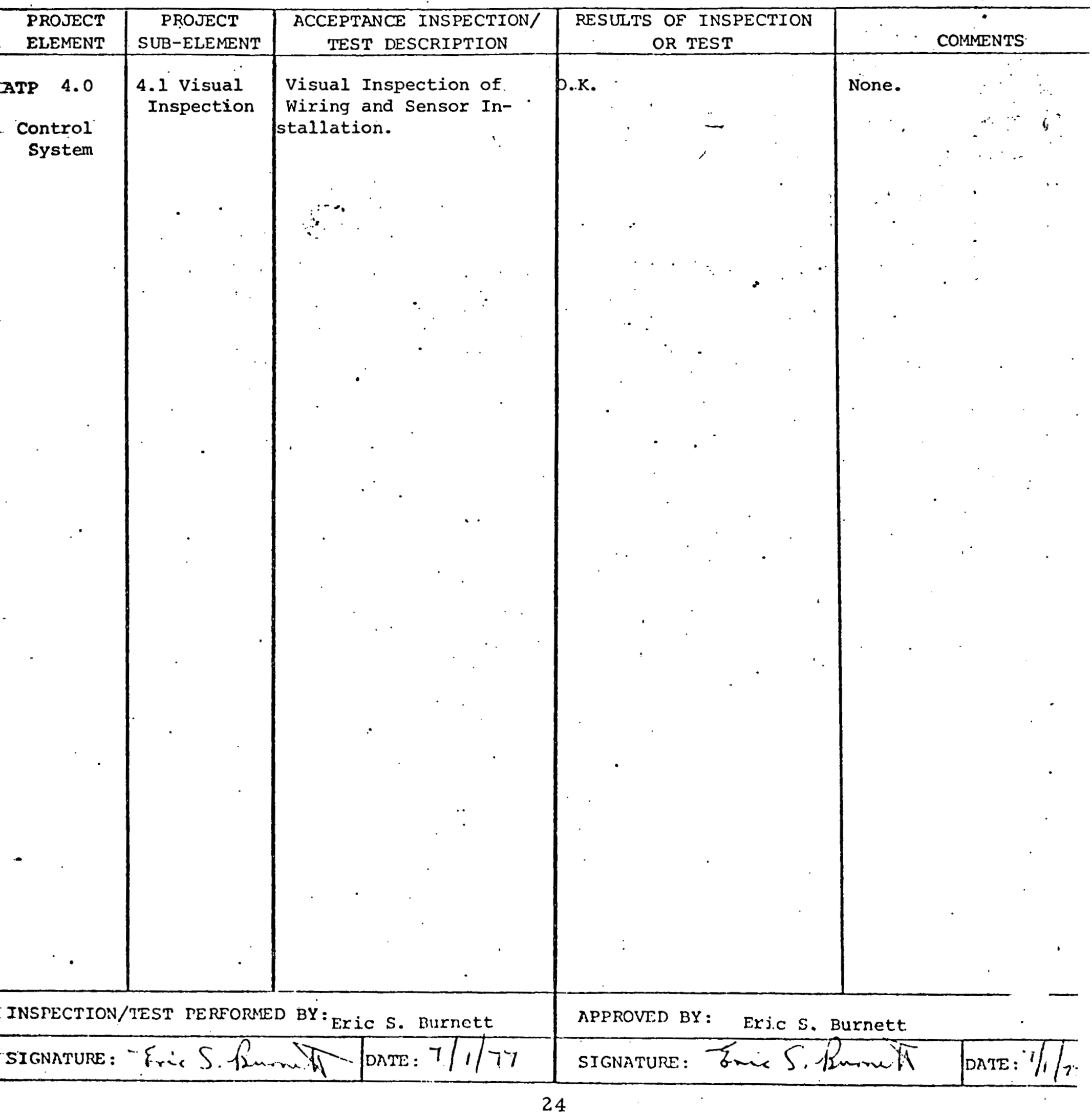




\section{ACCEPTANCE TEST OF THE SOLAR HOT WATER HEATING DEMONSTRATION PROJECT (INDUSTRIAL LAUNDRY) AT}

RED STAR INDUSTRIAL SERVICE

- 3333 SABRE AVENUE, FRESNO, CA

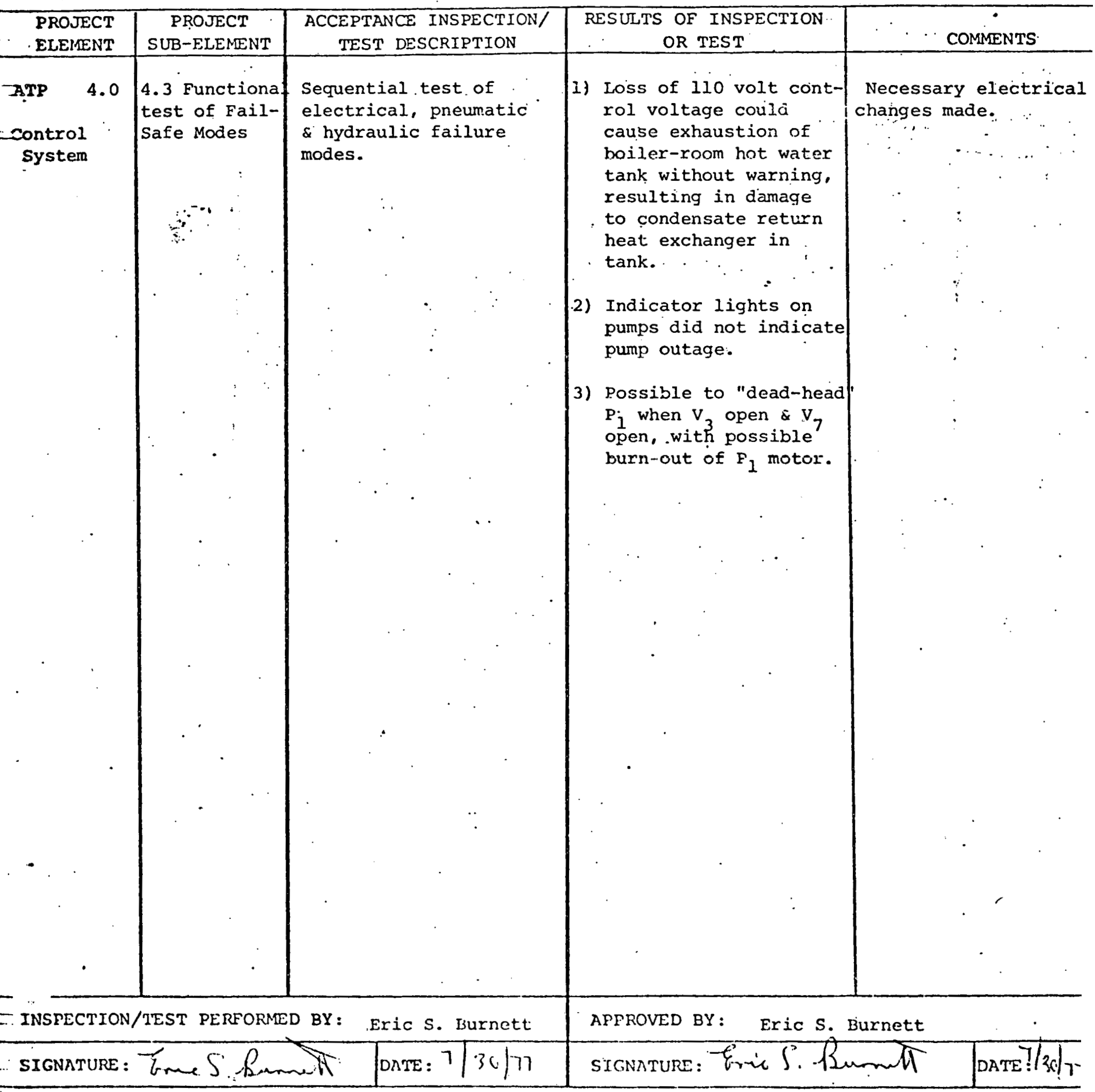


SECTION 2.1 .1

(Sheet 13 of 13 )

ACCEPTANCE TEST OF THE SOLAR HOT WATER -HEATING

DEMONSTRATION PROJECT (INDUSTRIAL LAUNDRY) AT

RED STAR INDUSTRIAL SERVICE

3333 SABRE AVENUE, FRESNO, CA

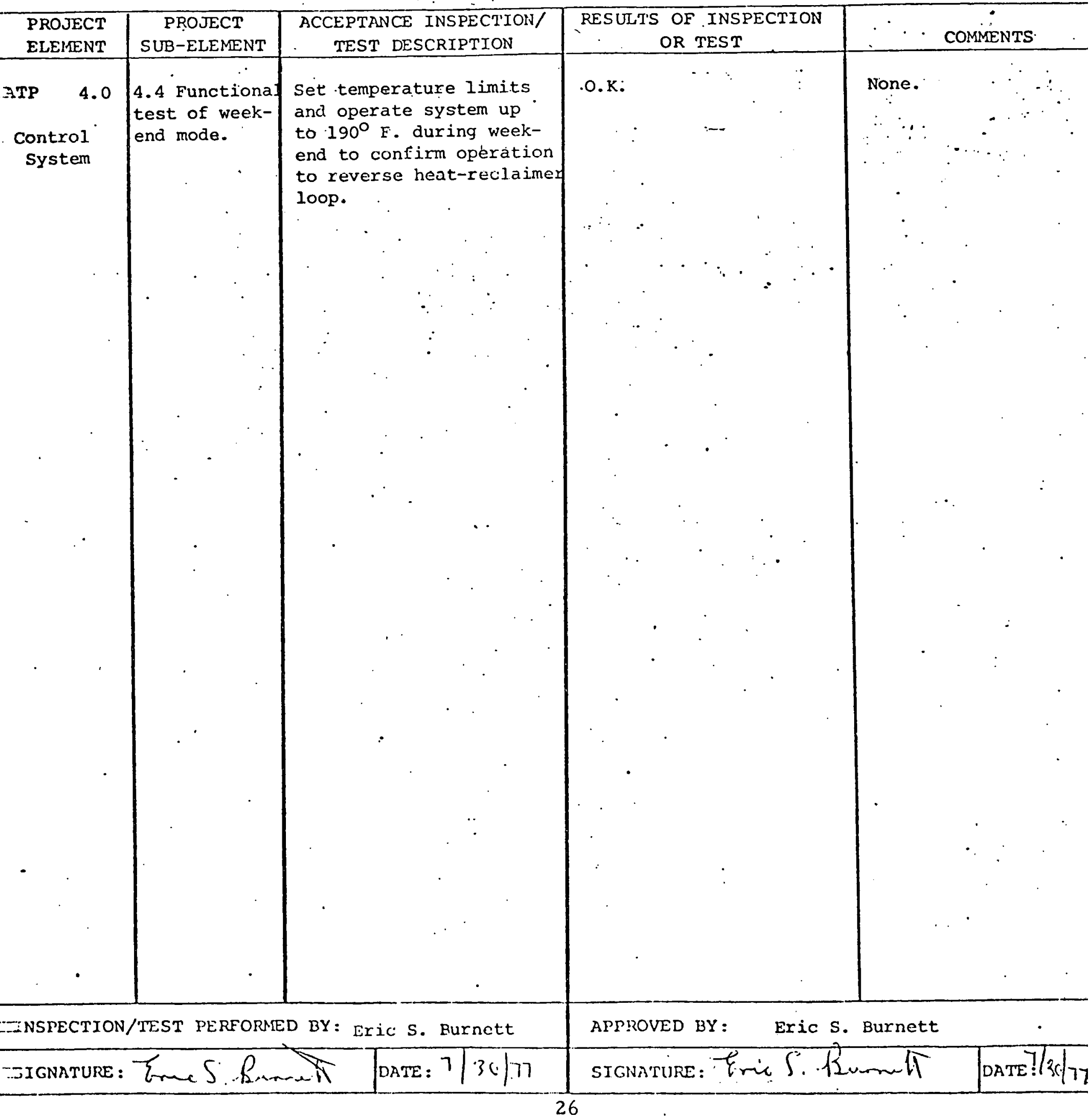


The Acceptance Test results and corrective actions are summarized in the data sheets of the previous section. Enumerated in this section are certain specific problems, the solutions of which are considered relevant to similar solar hot water heating installations for industrial applications.

\section{$1 \quad$ Assembly of Collector Tubes to Headers}

Having had difficulty in attaining a satisfactory acceptance rate for solar collectors in which the stainless steel tubes and headers had been brazed, the decision was made to use plasma arc welding throughout. This proved to be a very cost-effective technique for use with thin-wall stainless steel tubing, since process cost was more than offset by reduced rejection rates (2\%).

\section{$2 \quad$ Modification of Constant Flow Controllers}

At the time of initiation of the project, available constant flow controllers operating at $2.0 \mathrm{gpm}$ had an excessive pressure drop which could only be mitigated, but not completely eliminated by increasing the orifice diameter. More recently, improved units have become available from other manufacturers with better $\mathrm{P}-\mathrm{V}$ characteristics at low flow rates ( 1 to $2 \mathrm{gpm}$ ).

\section{$3 \quad$ Inadequate Roof Loading Factors}

Despite the use of the Ying collectors, with an installed roof loading factor of only $2 \mathrm{lbs} / \mathrm{ft}^{2}$, it proved impossible to meet all the requirements for resurfaging the roof in accordance with the specification of $300 \mathrm{lbs} / \mathrm{square}$ $\left(3 \mathrm{Ib} / \mathrm{ft}^{2}\right)$ without exceeding the maximum permissible loads in certain areas (see Section 7.0). Consequently, it was necessary to compromise through the use of light weight lava rock between the solar arrays and minimum gravel surfacing below the solar collectors.

\section{$4 \quad$ Integrity of Collector Support Structure Attachments}

The large number of penetrations for structural support of the collectors led to considerable problems in waterproofing the roof.' (Penetrations for plumbing caused minimal problems, since laterals, risers and headers could be flashed.) This problem has not bcen completely overcome at this time. Pressure injection of a hot sealant is being considered to mitigate the problem.

\section{Fail-Safe Modes of Opcration}

As discussed in Section 2.1, Sheet 12 of the Acceptance Test Plan data, preliminary system tests indicated the need for additional alarm circuits to mitigate against specific fault conditions. Additional alarm circuits were installed to provide audible and visual warning of these fault conditions, since which time the system has operated in a totaly "hands-off mode" for over $2 \frac{1}{2}$ years without a single malfunction. 


\section{SECTION 3.0}

\section{ENGINEERING DRAWINGS}

\section{WIRING AND PIPING SCHEMATICS}

Sheet 1 - Roof Solar Collector Array \& Sleeper Coordinates

Sheet 2 - Mechanical \& Control Schematir; Sequencing Logic

Sheet 3 - Piping \& Collector Details

Sheet 4 - Installation Details 


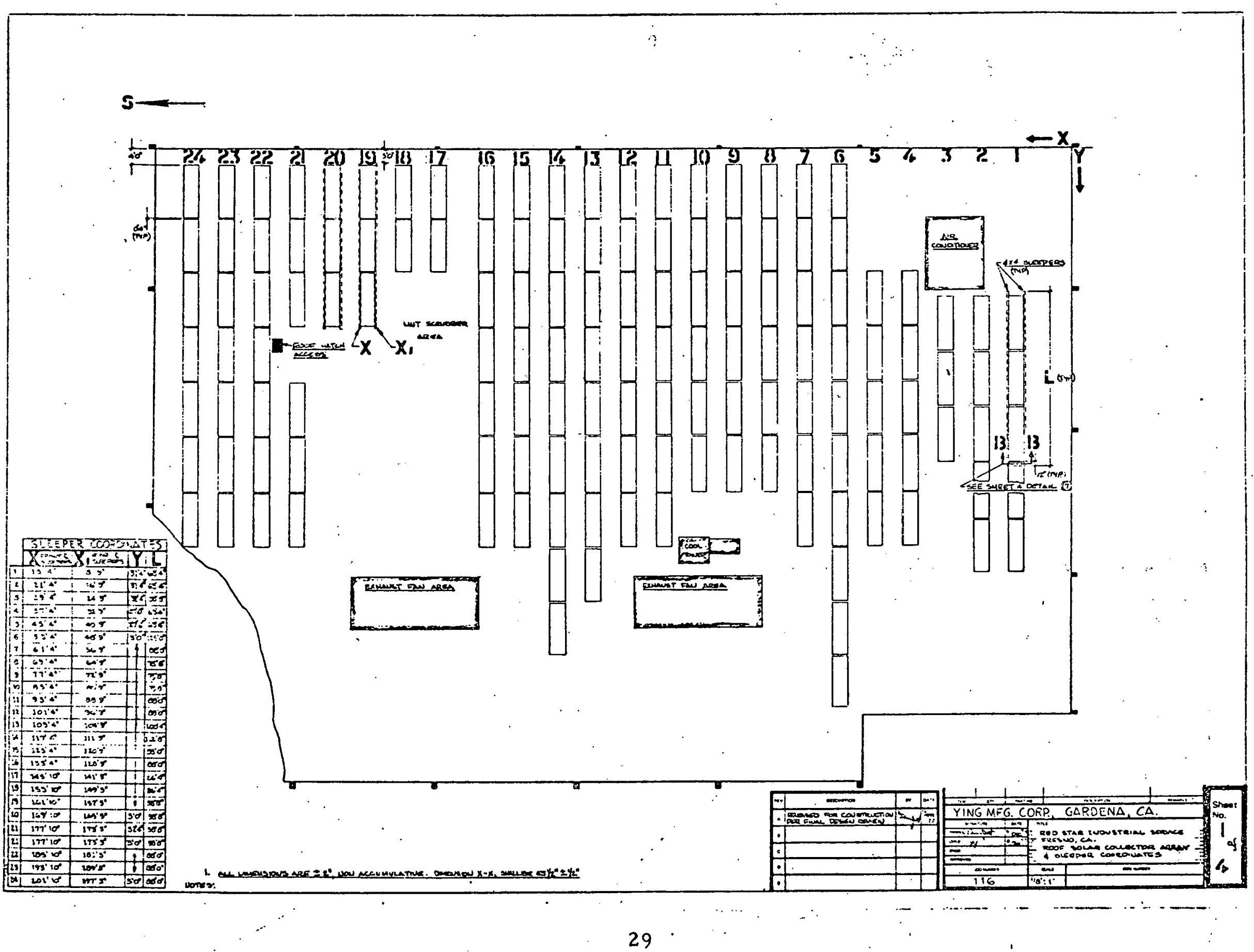




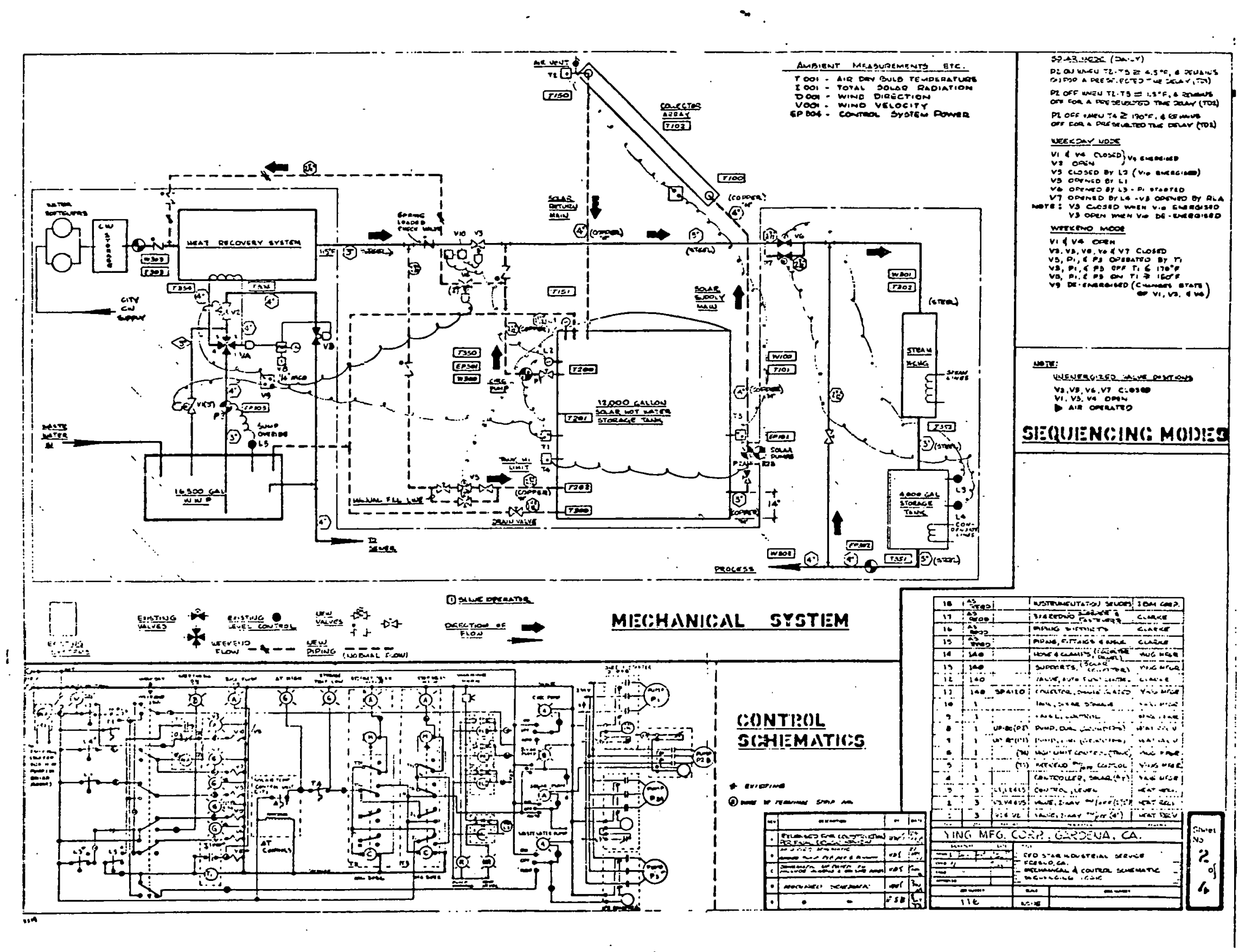




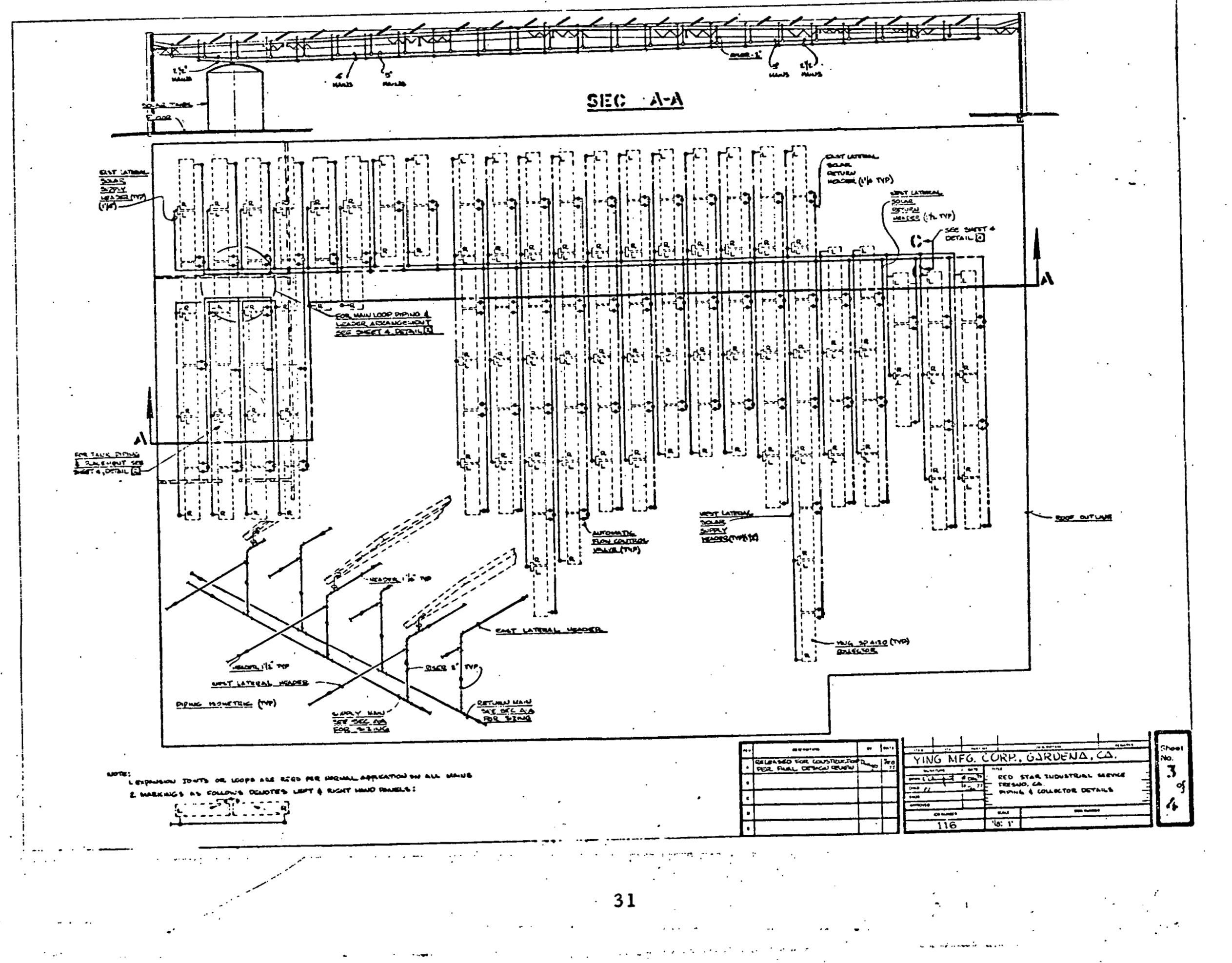




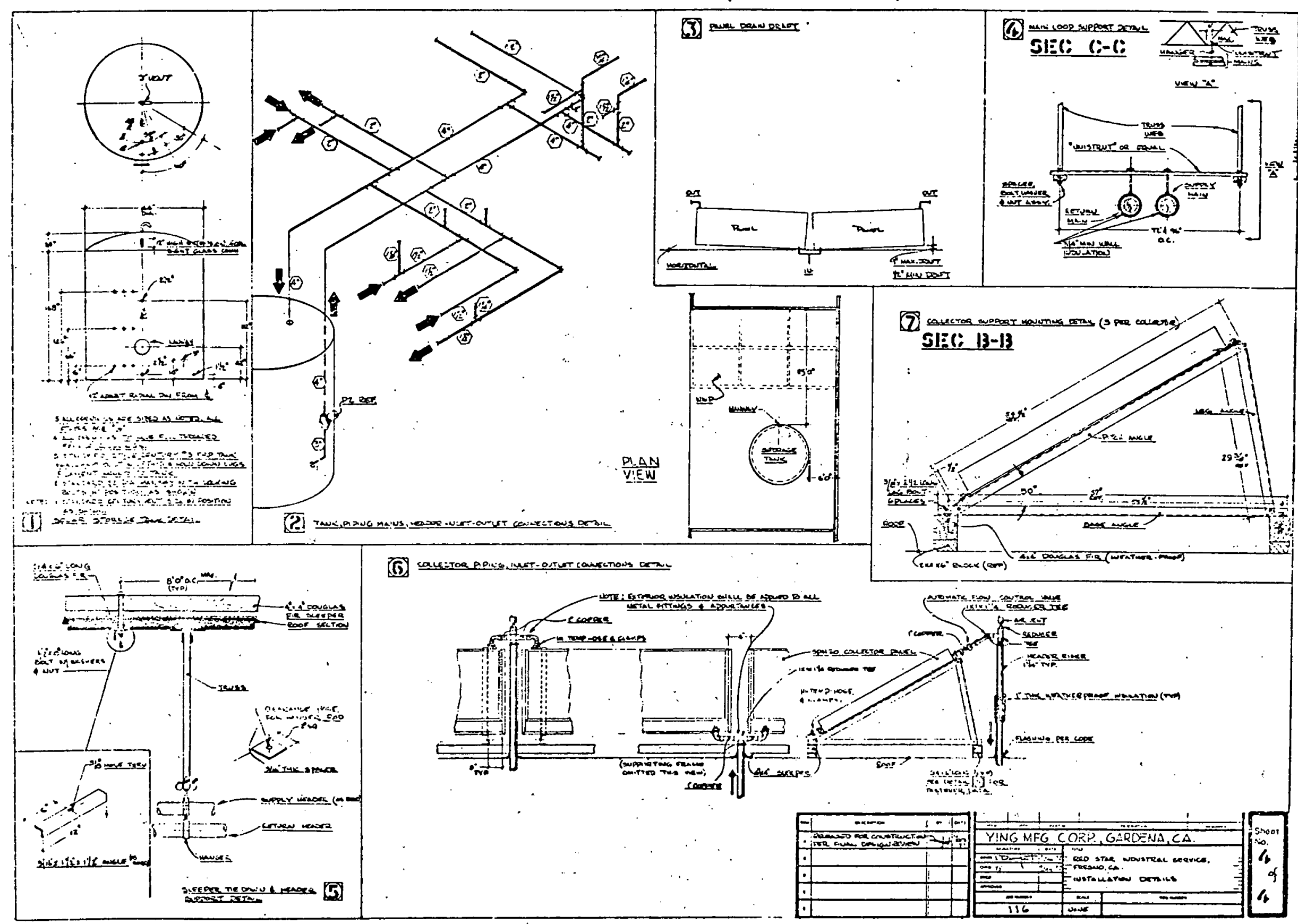




\section{SECTION 4.0}

OPERATION AND MAINTENANCE INSTRUCTIONS 


\section{SECTION 4.0 OPERATION AND MAINTENANCE INSTRUCTIONS}

\section{Introduction}

The total system as designed comprises three major subsystems:

- The wastewater heat recovery subsystem

- The solar subsystem

- The auxiliary hot water subsystem

Each subsystem is capable of independent operation. In the event of a malfunction of the wastewater heat recovery subsystem or the solar subsystem, either or both of the subsystems can be isolated from the auxiliary hot water subsystem. The system configuration allows all cold water coming Into the liul water.system, after being conditioned in the water softeners, to pass sequentially through the wastewater heat recovery subsystem, the solar subsystem and then to the auxiliary hot water subsystem, where the temperature is raised to $180^{\circ} \mathrm{F}$. for use in the plant. The subsystems are designed for a maximum flow rate of $200 \mathrm{gpm}$ of hot water. The system is fully automatic in operation at all times, whether in the "NCRMAL" mode of operation or the "WEEK-END" mode (see Subsection 4.1 below). The combination of level controls and temperature probes controls the operation of each of the subsystems. These controls will be described in Subsection 4.1. Audible and visual alarms are provided to indicate loss of control voltage, loss of any of the pumps in the system, low level in the solar hot water tank and low level in the auxiliary hot water tank (see Figure 4-1). Automatic shut-down and drain-down of the solar system, with appropriate time delays, is provided in the event that there is insufficient insolation or low level in the solar hot water storage tank. Dial gauges are provided to measure temperature and pressure in critical elements of the subsystems. Also provided is a display board which serves as a diagnostic tool in the event of a malfunction in addition to the alarms discussed above.

\section{SECTION 4.1 OPERATIONAL MODES}

Because lack of funding precluded providing the 23,000 gallons of storage capacity for the solar subsystem that the system design dictated, it was necessary to provide two distinct operational modes: namely, the "NORMAL" mode and a "WEEK-END" mode. This latter 
mode, never fully operational for reasons outlined below, was designed to transfer heat from the solar storage tank (with a capacity of 12,500 gallons) to the wastewater pit (with a capacity of 16,500 gallons) during week-ends and holidays. The purpose of this mode of operation was to ensure that the maximum amount of solar energy collected during week-end and holiday periods was utilized. With a maximum capacity of only 12,500 gallons and a temperature limitation on the fiberglass storage tank of $190^{\circ} \mathrm{F}$, additional storage was required under conditions of maximum insolation during the summer months, which could only be provided by using the thermal capacity of the wastewater pit. Unfortunately, operational considerations, which included the necessity to lower the level in the wastewater pit every other week in order to remove sludge from the pit, have precluded maximum utilization of this capability. This has undoubtedly led to some degradation in system performance, in addition to the added complexity that was added to the solar subsystem.

\section{SECTION 4.2 NORMAL MODE}

The "NORMAL" mode of operation is charaçterized by flow-through operation, with initial heat exchange via a three-section tube and shell heat reclaimer from the wastewater to the incoming softened water, followed by solar heating and storage in a 12,500 gallons storage tank from which water at a nominal temperature of $135^{\circ} \mathrm{F}$. is withdrawn on demand to the auxiliary hot water storage tank (4,000 gallons). In this tank the water is heated to $180^{\circ} \mathrm{F}$. by a steam/water heat exchanger prior to being used on deinand by the plant. (The overall system schematic is depicted in Figure 4.1 below.) As a sub-mode of operation, as discussed earlier, it is possible to by-pass either the wastewater heat recovery subsystem or the solar storage subsystem in the event of malfunction. Isolation of the wastewater heat recovery subsystem is performed manually using gate by-pass valves. Isolation of the solar subsystem is performed automatically by the de-activation of $v-3$, which effectively bypasses the solar storage tank.

During the "NORMAL" mode of operation the sequence of events is as follows:

1. Hot water demand on the auxiliary hot water tank activates a level control ( $L-3$ in the mechanical and control schematic diagram, reproduced as Figure 4.1 in this section of the report), to open $V-6$, allowing preheated water from the solar storage tank to be transferred by $\mathrm{P}-1$ to the auxiliary storage tank. Water withdrawn from the solar storage tank is replaced when $L-1$ level control in the solar storage tarik opens $V-5$, allowing fresh water to flow into the storage tank via the wastewater heat recovery 


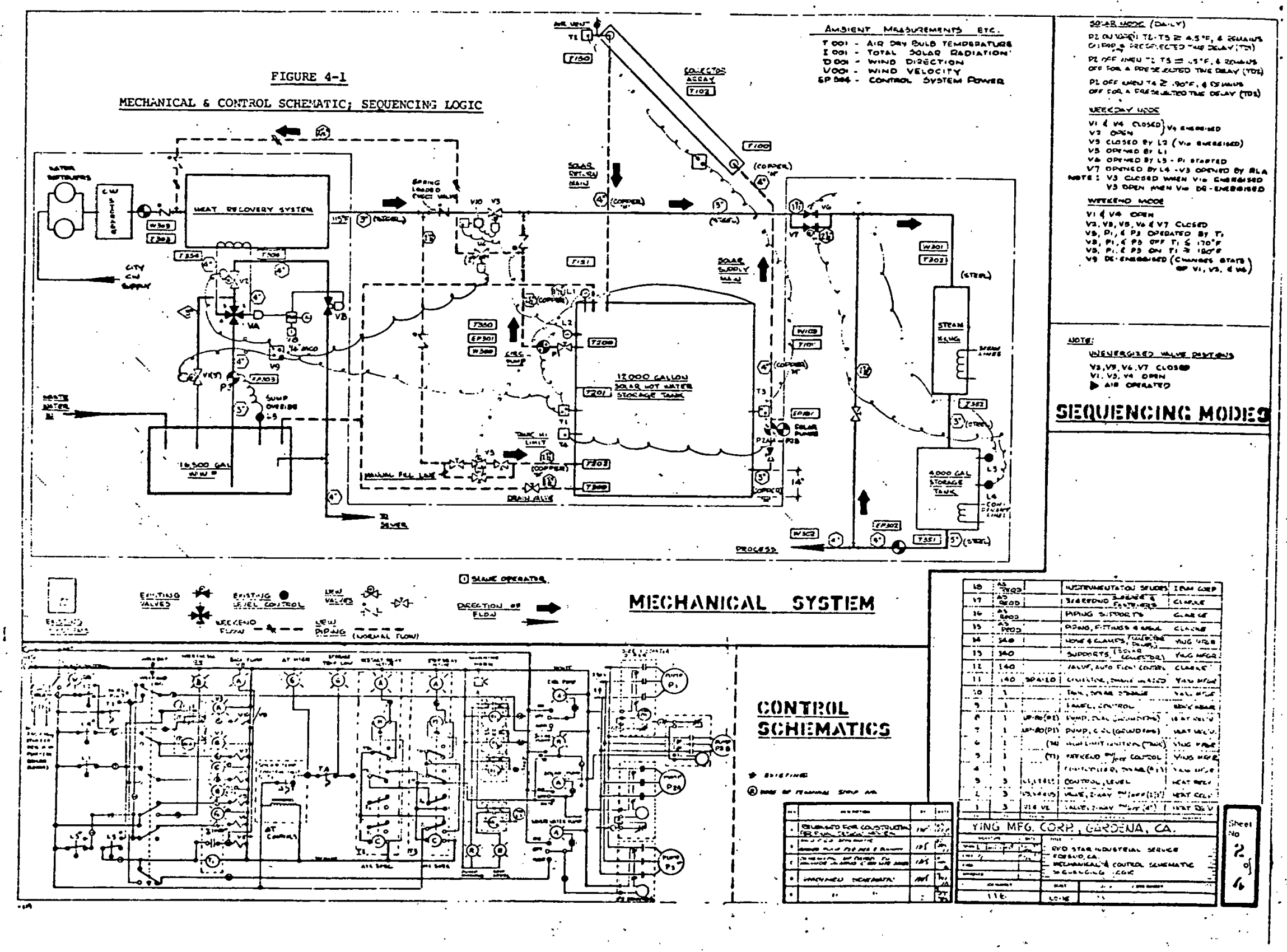


exchanger through V-5, which is an electrically actuated valve. In the event that there is an unusually heavy demand for hot water from the auxiliary storage tank, level control $L-4$ on this tank activates $V-10$, an electrically operated pilot valve which in turn activates $V-3$, thereby. providing additional flow from the wastewater heat exchanger directly through the large diameter by-pass valve $V-7$ to the auxiliary storage tank. Under' these conditions, fresh water is being supplied both from the solar storage tank by $\mathrm{P}-1$ and from the wastewater heat exchanger directly through V-3, passing to the auxiliary storage tank through V-6 and V-7, both of which are open at this time.

Provided there is sufficient wastewater in the pit, as indicated by closure of level control L-5, the wastewater circulating pump will be activated whenever there is a demand for fresh water by the solar storge tank, as indicated by level control $\mathrm{L}-1$ closure and the opening of $\mathrm{V}-5$. Timer $\mathrm{T}-\mathrm{l}$ runs whenever the wastewater pump is operating and is used to operate valve $V-A$ : a four way Dezurik valve designed to enable the wastewater heat exchanger to be back-flushed. Identical timers T-2 and T-3 are used, respectively, to initiate or discontinue circulation of water through the solar collectors after preset delays. Solar pumps $\mathrm{P}-2 \mathrm{~A}$ and $\mathrm{P}-2 \mathrm{~B}$ are activated by these timers, which serve to minimize circulation of water through the solar collectors during periods of intermittent insolation caused by clouds or spurious start-up at the beginning of the day.

A solar temperature control unit inhibits operation of the solar collector loop when the temperature difference between the collectors and the solar storage tank temperature is less than $4.5^{\circ} \mathrm{F}$. Similarily, this same unit shuts off $\mathrm{P}-2 \mathrm{~A}$ and $\mathrm{P}-2 \mathrm{~B}$, allowing the solar collectors to drain back to the solar storage tank when the tempcrature differential between the solar collectors and the storage tank is less than $1.5^{\circ} \mathrm{F}$.

\section{$\underline{V}_{3}$ Operation}

To guard against failure of water supply to the boiler room, which could be serious if allowed to go uncorrected, valve $v_{3}$ is allowed to remain open (springloaded) under the following conditions:

- No control voliage

- No air supply 
- Low level control $\mathrm{L}_{2}$ open, indicating low level in solar storage tank.

- Demand from $\mathrm{L}_{4} / \mathrm{V}_{7}$ for high.water rate.

Under all other conditions in the "NORMAL" mode of operation, $V_{3}$ is closed, to allow all water to the auxiliary. hot water system to flow through the solar storage tank.

In the "WEEK-END" mode of operation (see below), there is no air supply and $V_{3}$ is open, guarded against back-flow by a spring-loaded check valve.

\section{SECTION 4.3 "WEEK-END" MODE}

In the "WEEK-END" mode of operation, activated by a manually controlled switch on the control panel, the solar collector loop and P-2A/P-2B still operate under automatic control of the solar temperature unit. In this mode of operation, neither cold water nor compressed air are normally available for use by the subsystems. Consequently, all valves and controls in this mode have to be electrically operated or make use of spring-return for actuation. Excluding only the solar collector circulation loop, all controls and pumps are normally quiescent until the temperature of the water in the solar storage tank reaches $170^{\circ} \mathrm{F}$. Through closure of temperature sensor $\mathrm{T}-1$, water from the solar storage tank is circulated by $\mathrm{P}-1$ through $\mathrm{V}-4$ and the wastewater heat exchanger back to the solar storage tank via V-5. Simultaneously, the wastewater pump P-3 is activated to circulate wastewater through the heat recovery unit, thereby transferring heat from the solar storage tank to the wastewater pit. This mode of operation continues until the temperature of the solar storage tank drops to $160^{\circ} \mathrm{F}$, at which point the recirculating loop is disabled by the opening of $\mathrm{T}-1$; the same controller that had been used for initiation of the recirculation cycle. It should again be emphasized here that all temijerature and Icvel cuntruls have a differential band over which they operate. This feature contributed significantly to the simplification of the control system for this project.

In the unlikely event that the temperature in the solar storage tank reaches $190^{\circ} \mathrm{F}$., temperature controller T-4 disables the solar collector circulating loop, allowing the collectors to drain back into the storage tank. This condition obtains only if the level in the wastewater pit is too low to allow the wastewater pump P-3 to be activated via $\mathrm{L}-5$, thereby inhibiting heat transfer to the wastewater pit.

For diagnostic purposes, supplemented by alarm and display circuits discussed earlier, all pumps can be operated manually from the coritrol panel. Alarm circuits and the display board allow for near instantaneous diagnosis of any major system component failure. 


\section{SECTION 4.2 CONTROL LOGIC AND TEMPERATURE RANGES}

The operational modes described in Section 4.1 of this report are summarized in the tables below.

Data presented in these tables describe the types of control components and pumps used and the modes of operation.

\section{TABLE 4-1 COMPONENT TYPES, RANGES \& MANUFACTURERS}

\section{Valve Operation Setting De-Activated}

\section{Component Electric Pneumatic High Low}

$\mathrm{V}_{\mathrm{A}}$

$v_{B}$

$v_{1}$

$\mathrm{v}_{2}$

$v_{3}$

$v_{4}$

$v_{5}$

$v_{6}$

$v_{7}$

$v_{8}$

$v_{9}$

$v_{10}$ $\mathrm{x}$

$x$

$\mathbf{X}$

$\mathrm{X}$

$\mathrm{x}$

$x$

$x$

$\mathrm{x}$

$x$

$\mathrm{X}$

$x$

$x$
State

\section{Manufacturer Comments}

ITT - Grinnell Timed Back Flush Via $V_{8}$

ITT - Grinnell Slaved to $V_{8}$ :

ITT - Grinnell Slaved to $V_{9}$

0

ITT - Grinnell "

0

DeZurick

Slaved to $V_{10}$

c

DeZurck

Slaved to $V_{9}$

C

ASCO

C Marfed

Marfed

Asco

Asco

Asco
Activated by $L_{1}$

Activated by $\mathrm{L}_{4}$

Actuates $\mathrm{V}_{\mathrm{A}} \& \mathrm{~V}_{\mathrm{B}}$

Actuates $V_{1}, V_{2} \& v_{4}$

Actuates $V_{3}$
Activated by $\mathrm{L}_{3}$ 
TABLE 4-1 COMPONENT TYPES, RANGES \& MANUFACTURERS

\section{Valve Operation Setting De-Activated \\ Component Electric Pneumatic High Low State Manufacturer Comments}

$P_{1}$

$P 2_{A} \& P 2_{B}$

- Grundfos

- * Hydr $-\mathrm{O}-\overline{\mathrm{MT}}$ atic

Activated by $L_{1}$ or $T_{1}(W / E)^{1}$

$\mathrm{P}_{3}$

PACO

Activated by $L_{1}$ or $T_{1}(W / E)^{L}$

3

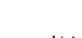

$$
L_{1}
$$

$12^{\circ} \cdot 10^{\circ}$

0

ASCO

Solar Storage Demanid

$\mathbf{L}_{2}$

11. 9

C

Asco

Low Level

$\mathrm{L}_{3}$

$$
\text { 5' 4' }
$$

0

ASCO

Normal H.W'. ${ }^{2}$ Demand

$$
\mathrm{L}_{4}
$$

4! 3

0

ASCO

Heavy H.W. ${ }^{2}$ Demand

$\mathrm{L}_{5}$

$-2^{\prime}$

o $\quad$ Mercoid

W.W. ${ }^{3}$ low level.

$T=T_{2}-T_{3}$

$4.5^{\circ} \mathrm{F} .1 .5^{\circ} \mathrm{F}$

$170^{\circ} 1 \cdot 16^{\circ} \mathrm{F}$

0

$\wedge$ sco

Dump to W.W. ${ }^{3}(W / E)^{1}$

$T_{4}$

$190^{\circ} \mathrm{F} \cdot 168^{\circ} \mathrm{F}$.

C

ASCO

High Temperature Over-ride

\section{$\underline{\text { KEY }}$}

W/E - "Weck-End Mode"

$\frac{1}{2}$ H.W. - Hot Water

$\frac{2}{3}$ W.W. - Wastewater 
TABLE 4-2 OPERATIONAL MODES \& CONTROLS FOR PUMPS

Function/Operation

\section{P-1 Operation}

Normal water demand to auxiliary $(4,000$ gal) tank

Heavy Water Demand* to auxiliary tank.

- P-2 Operation

Collector $4.5^{\circ} \mathrm{F}$ above

"NORMAL" Mode

$\underline{P}_{1} \quad \underline{P}_{2} \quad \underline{P}_{3}$

ON

ON
"WEEK-END" Mode

$\underline{\mathbf{P}}_{1} \quad \underline{\mathrm{P}}_{\underline{2}} \quad \underline{\mathrm{P}}_{\underline{3}}$

Control Element
: $\quad$ storage water temperature

Collec tor $1.5^{\circ} \mathrm{F}$ below

$\therefore \quad$ storage water temperature

Storage Water $\geq 190^{\circ} \mathrm{F}$

Storage Water $\geq 190^{\circ} \mathrm{F}$

\section{P-3 Operation}

Low Level in Wastewater sump

Water demand to solar tank \& sump level O.K.

OFF

ON
$\mathrm{L}_{3}$

$\mathrm{L}_{4}$

OFF

$\Delta \mathrm{T}$

OFF
OFF

$O N \quad \therefore \triangle T$

$T_{4}$

$\mathrm{L}_{5}$

$\mathrm{L}_{1}$

OFF

OFF

$\mathrm{T}_{1}$

ON

ON

* $v_{3}$ also opens via $v_{10}$ 
TABLE 4-3 CONTROL VALVE LOGIC

\begin{tabular}{|c|c|c|c|c|c|c|c|c|}
\hline Operational Mode & $\underline{v}_{A}$ & $\underline{v}_{B}$ & $\underline{v}_{1}$ & $\underline{v}_{\underline{2}}$ & $\underline{v}_{3}$ & $\underline{v}_{-}$ & $\underline{v}_{5}$ & $\underline{v}_{6}$ \\
\hline WEEKDAY & * & 0 & $x$ & 0 & $\otimes$ & $x$ & $\otimes$ & 0 \\
\hline WEEK-END & * & $x$ & 0 & $x$ & 0 & 0 & $\otimes$ & $x$ \\
\hline
\end{tabular}

* Back Flush Valve for Heat Reclaimer

$$
\text { KEY } O=\text { OPEN } X=\text { CLOSED } \quad \text { OPE } \bar{N} / C L O S E D \text { ON DEMAND }
$$

For completeness in this section of the report, electrical interfaces to the boiler room are shown in Figure 4-2 below. External connections to the Control Panel are shown in Figure 4-3. Excluding only the pneumatic interfaces to contiol valves (and IBM instrumentation), all other interconnections are made within the pre-fabricated control panel, which was manufactured off-site by Ying Manufacturing Corporation.

FIGURE 4-2 ELECTRICAL INTERFACES BETIVEEN BOII.ER ROUM \& CONTROL PANEL

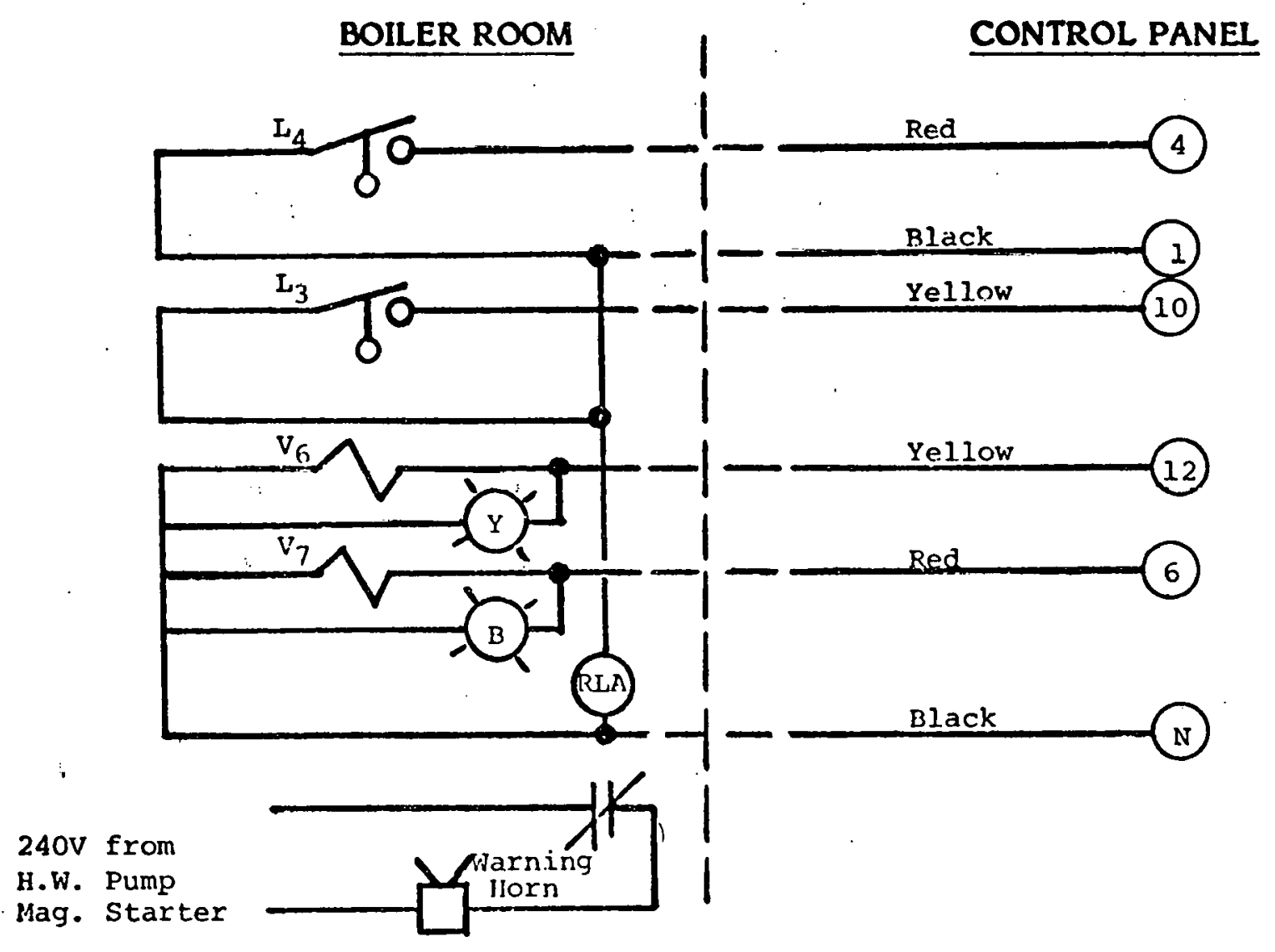


FIGURE 43 EXTERNAL ELECTRICAL INTERFACES TO CONTROL PANEL

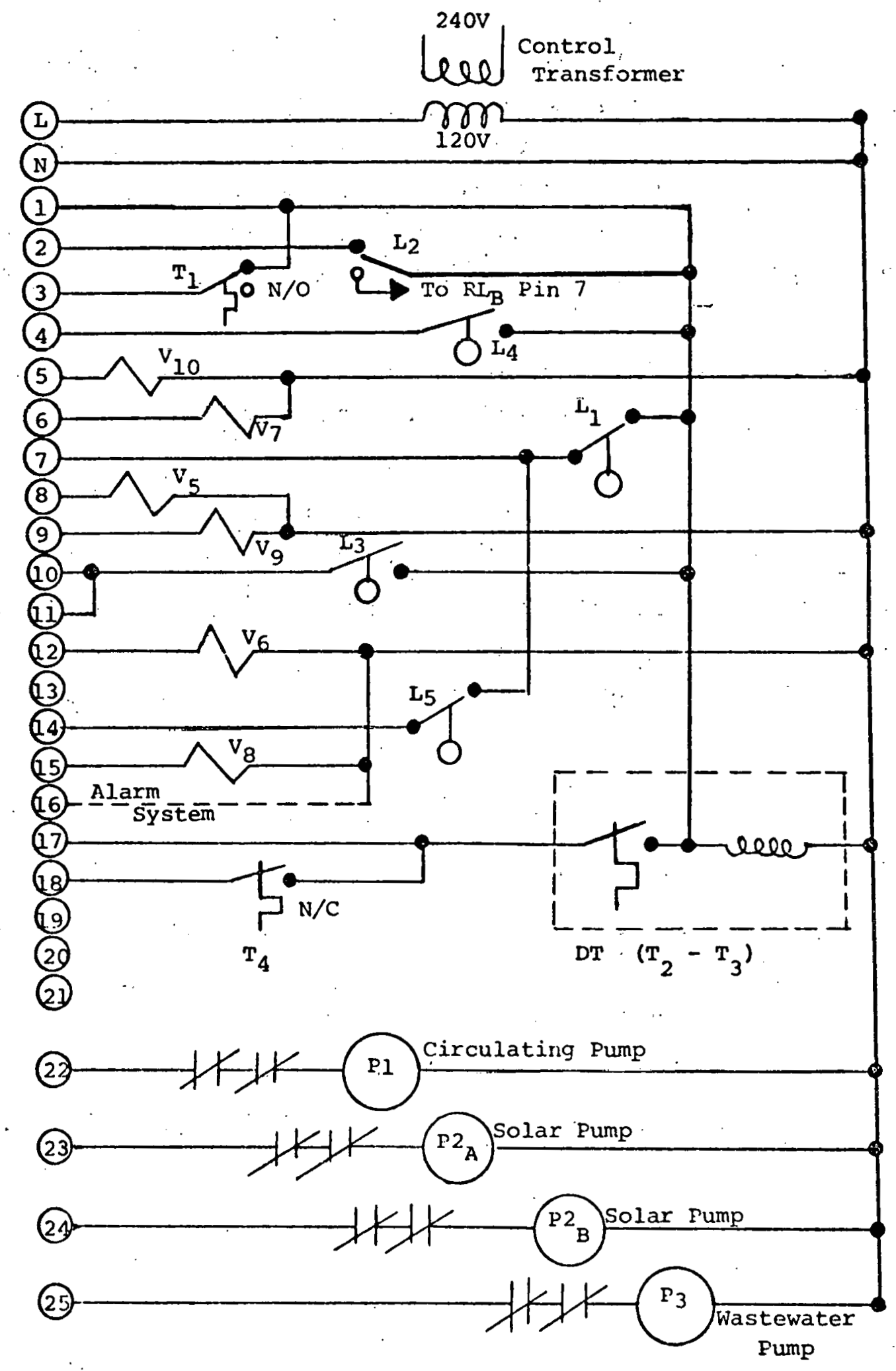




\section{SECTION 4.3 SYSTEM START-UP \&' PREVENTATIVE MAINTENANCE}

Following pressure testing of each subsystem, level sensors $\mathrm{L}_{1}, \mathrm{~L}_{2}, \mathrm{~L}_{3}$ and $\mathrm{L}_{4}$ are calibrated, using the manometers on the solar storage and auxiliary (4,000 gallon) tanks. Bypass valves on each manometer are used to ver ify calibration of these sensors, including high and low settings for each sensor. Temperature sensors $T_{1}$ and $T_{4}$ are calibrated using a digital-readout precision thermometer and thermostatically controlled water bath prior to installation in the solar storage tank. "The $\Delta T$ sensor is similarily calibrated prior to installation.

After conventional continuity and resistance checks, direction of rotation of pumps $\mathrm{P}_{1}, \mathrm{P}_{2}, \mathrm{P}_{2} \mathrm{~A}$ and $\mathrm{P}_{3}$ is checked in the "MANUAL" mode prior to activation of the "AUTO" mode of operation.

Start-up tests are completed by checking state and operation of each valve in the system in accordance with the sequences defined in Figure 4-1 and Tables 4-1 and 4-2.

Initial validation of systems performance and potential malfunctioning is performed by exercising each control subsystem manually, prior to activation of automatic modes. Thereafter, alarm circuits and the display board are used to indicate any system malfunction.

Routine, preventative maintenance is limited to the following:

- Cleaning of Solar Panels every week

- Check of wastewater heat recovery subsystem performance by reading chart recorders every day.

- Pneumatic fecd system integrity and lubrication checks once per month

- Visual and audible checks of pump operation every month

- Visual checks of analog instrumentation for possible system malfunction once a week.

All major malfunctions are automatically identified and alarmed through the alarm and display system. 


\section{SECTION 5.0}

PHOTOGRAPHS 


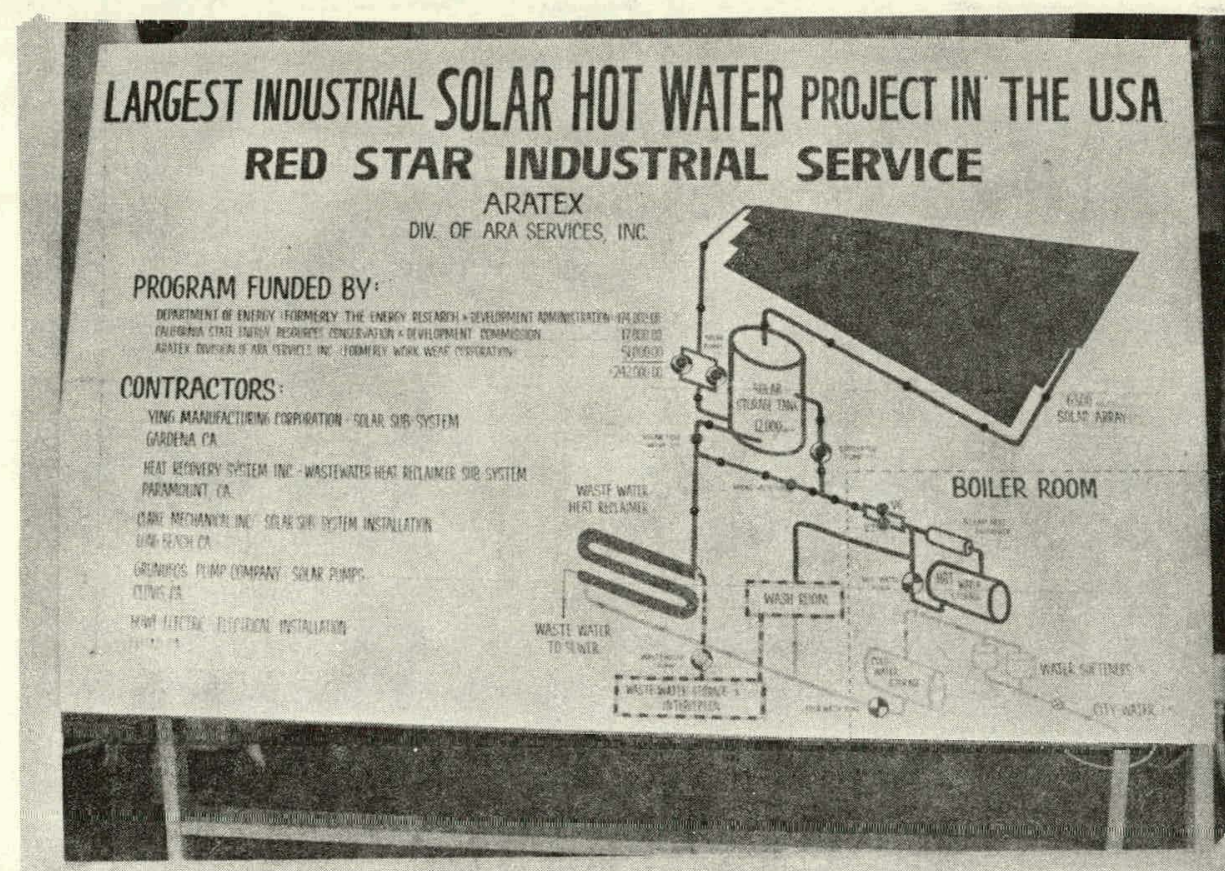

Figure 5.1

Diagnostic

Display

Board

rigure 5.2

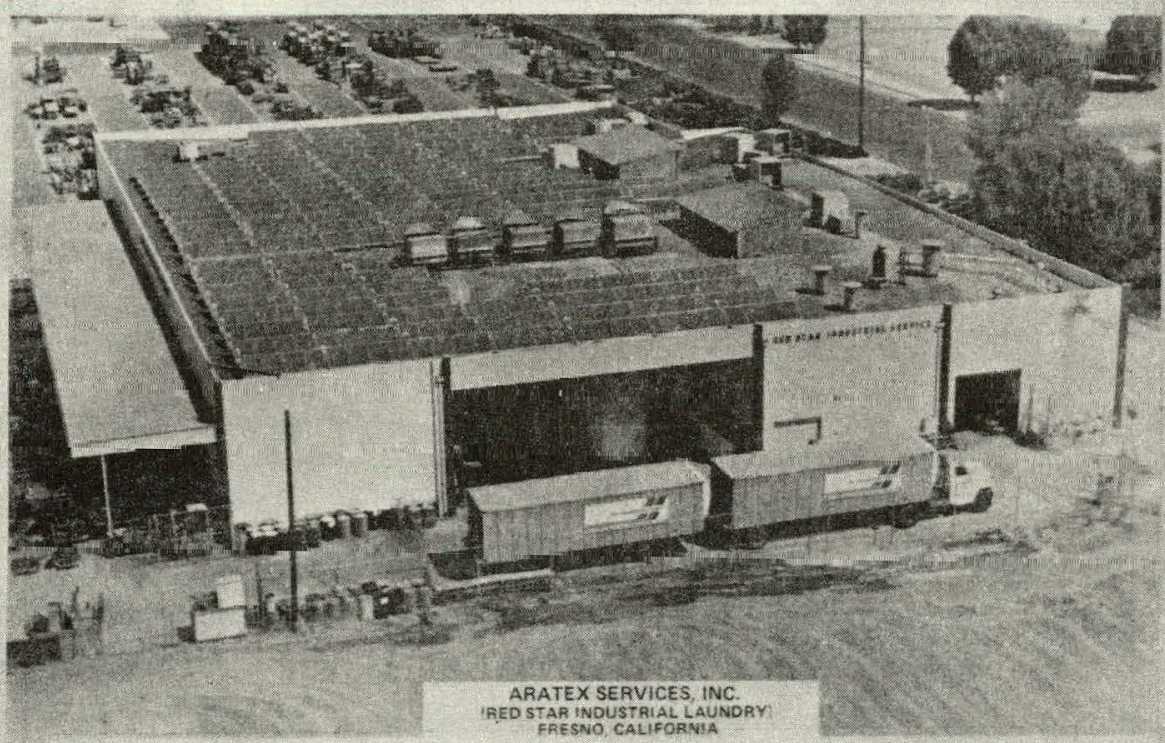

Figure 5.3

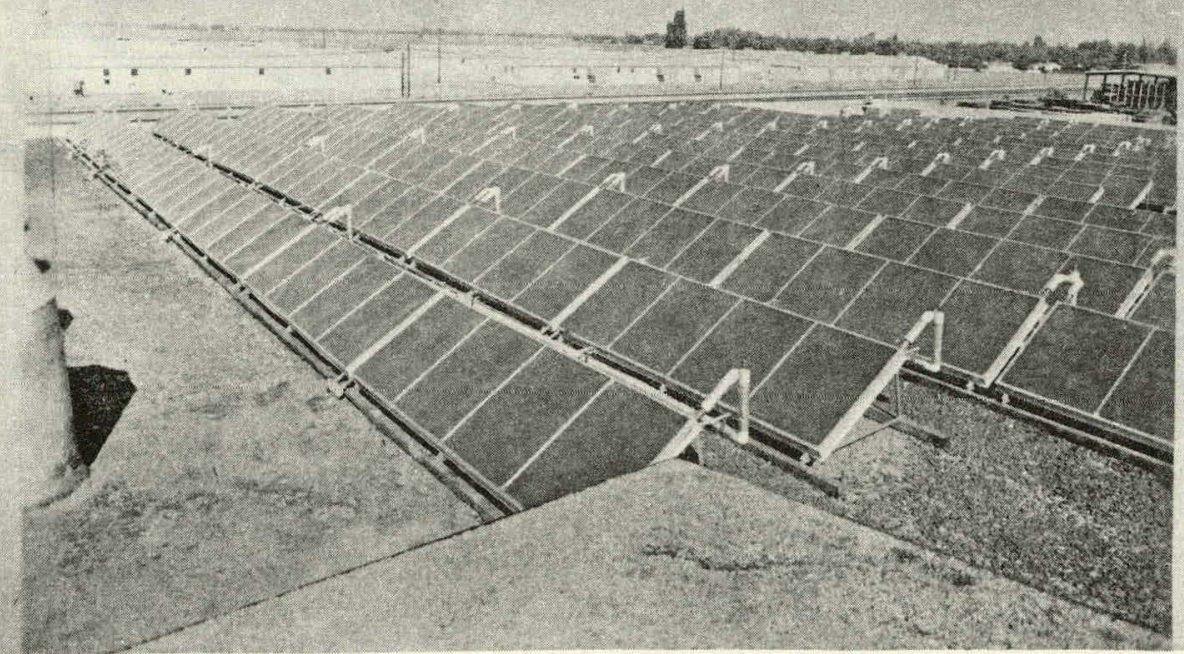

Close-up of

Completed

Collector

Array. 


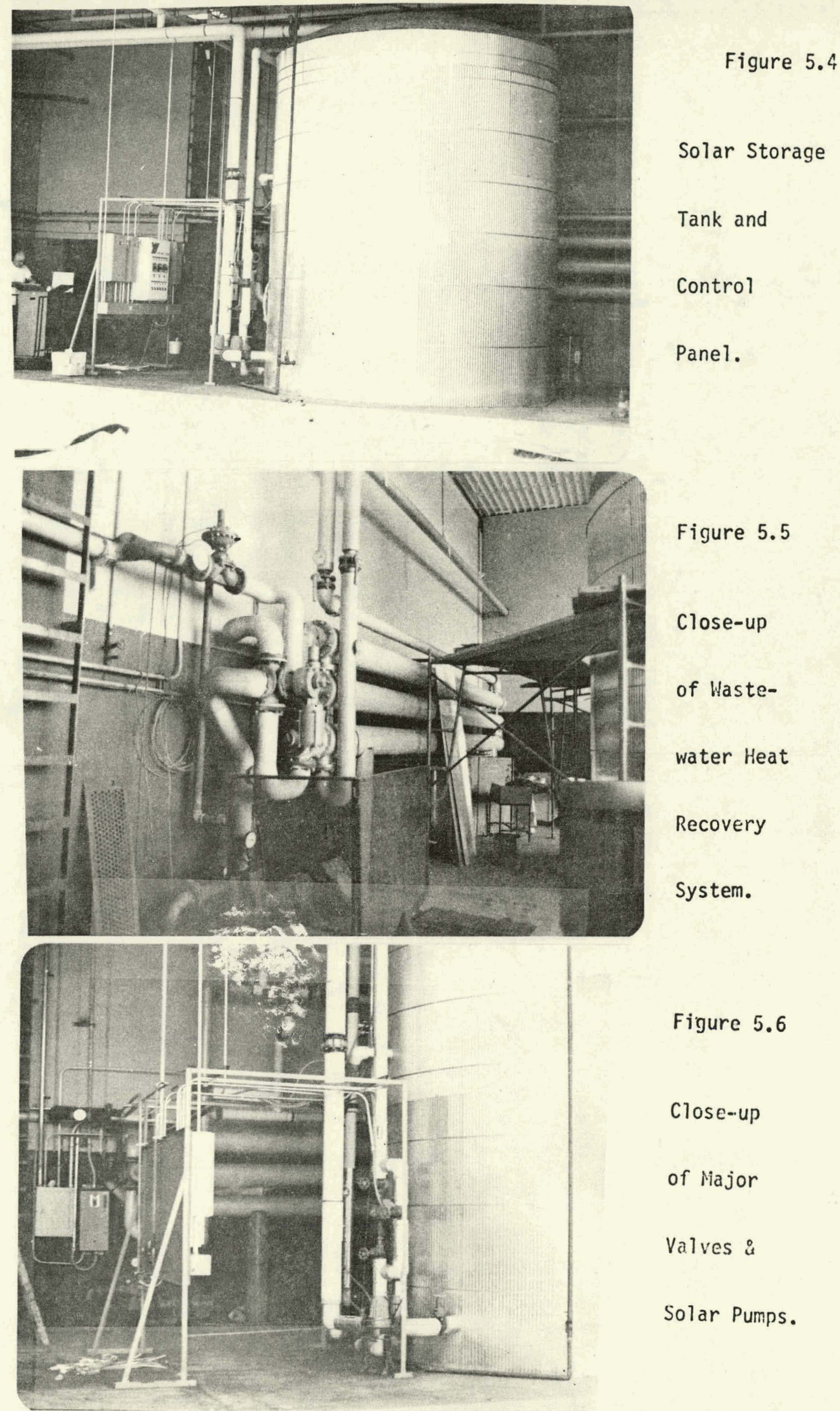


SECTION 6.0

PERFORMANCE PREDICTIONS AND RESULTS TO-DATE 


\section{SECTION 6.0 PERFORMANCE PREDICTIONS}

In this section of the final report, thermal balance analyses and performance predictions, originally submitted to NASA/MSFC on January 17, 1977 as a part of Progress Report No. 3, are reproduced for completeness and self-consistency. Comparison with data gathered by the National Solar Data Network is still incomplete at this time, due to problems with the sensor calibration. However, there is some indication that degradation of the solar panels due to stagnation and unusual weather problems has caused a shortfall in performance, which can only be corrected if the panels are resuifaced and re-glazed (see Section 7.0 of this report). Thermal balance analyses and other theoretical performance data are presented below, based on the original design criteria used at the start of the project.

\section{SECTION 6.1 THERMAL BALANCE ANALYSES}

In deriving the thermal balance for the hot water system at Red Star Industrial Service Laundry, 3333 No. Sabre Avenue, Fresno, Ca., it was necessary to make certain assumptions which could only be fully validated after the site was instrumented by IBM. Changes in processes and equipment which had occurred during the last three years made it difficult to compare data acquired in 1975 with current data. Nevertheless, by using a normalized Figure-of-Merit (FM), which related the gallons of hot water generated under standardized temperature conditions to therms of natural gas consumed by the hot water system, it was possible to project system performance under three different sets of conditions:

- Auxiliary system only (235 BtiP Babcock \& Wilcox Steam Boiler)

- Auxiliary system plus wastewater heat reclamation subsystem

- Auxiliary system plus wastewater heat reclamation and solar subsystems

Assumptions made in this analysis were as follows:

- Hot water accounts for $75 \%$ of the total water usage in the plant. (Recently reduced to $50 \%$ of total water usage by in-process conservation) 
- Boiler thermal efficiency was assumed to be 75\%, discounting other system losses such as evaporation, etc. $\frac{1}{-}$

- Incoming water temperature is $65^{\circ} \mathrm{F} .-\frac{2}{\text {; }}$ hot water temperature is $180^{\circ} \mathrm{F}$.

- Total number of hours of operation/year $=2,080$.

Figure 6-1 shows the flow diagram for water and steam in the plant, including existing heat conservation systems using steam condensate.

$1 \quad$ National Solar Data Network (IBM) analyses assume $60 \%$.

2 Average incoming temperature is actually $75^{\circ} \mathrm{F}$. 
EIGURE 6-1

THERMAL BALANCE FIOW DIAGRAM FOR

RED STAR INDUSTRIAL SERVICE

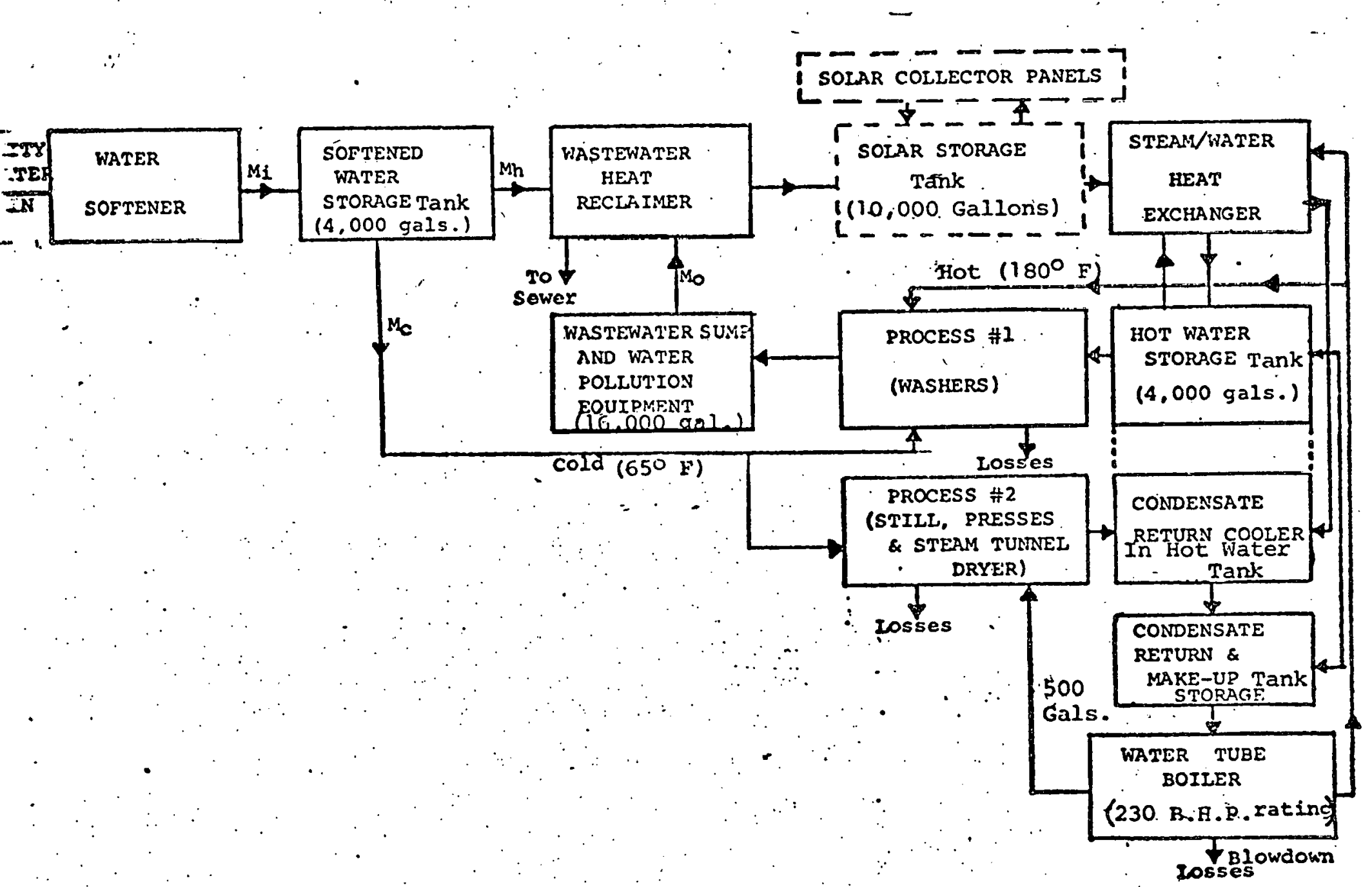


A. Based on data acquired from January 1975 to June 1975 inclusive (before installation of wastewater heat recovery system and steam drying tunnel),

Estimated 1975 water consumption $=13.938 \mathrm{Mg} /$ year $=6,700 \mathrm{gph}$

Estimated 1975 gas consumption $=274,750 \mathrm{Ther} \mathrm{ms} / \mathrm{yr}=132 \mathrm{Therms} / \mathrm{hr}$.

\section{Assume a boiler efficiency th of $75 \%$}

Then thermal input $=0.4463$ Therms $/ \mathrm{BHP}$

and thermal output $=33,472 \mathrm{BTU} / \mathrm{BHP}$.

Considering hourly flow and thermal transfer, based on above assumptions.

Hot water flow $=\frac{13.938 \times 10^{6}}{2,080} \times 0.75$ gallons $/$ hr.

$$
=5,026 \text { gallons/hour }
$$

Heat required to heat from $65^{\circ} \mathrm{F}$. Io $180^{\circ} \mathrm{r}$.

$$
\begin{aligned}
\mathrm{Q}_{\mathrm{H}} & =5,026 \times 8.33 \times(180-65) \mathrm{BTU} / \text { hour } \\
& =4,815,000 \mathrm{BTU} / \text { hour }
\end{aligned}
$$

At $75 \%$ boiler efficiency, energy input to boiler

$$
\begin{aligned}
\mathrm{Q}_{\mathrm{H}} & =\frac{48.15}{0.75} \text { Therms/hour } \\
& =64.2 \text { Therms/hour }(\% \text { of total }=48.64)
\end{aligned}
$$

Process steam for stills \& presses in this example (no steam tunnel) requires an additional thermal input to the boiler $\left(Q_{p}^{\prime}\right)$.

$$
\mathrm{Q}_{\mathrm{P}}^{\prime} \quad=15.0 \text { Therms/hours (\% of total }=11.36 \text { ) }
$$

Similarily, the gas turnbler dryers are assumed to consume $30 \%$ of the total gas consumption, with the remainder being made up by evaporation and other losses.

i.e. Q'TD

$=39.6$ Therms/hour $(\%$ of total $=30.00)$

Q'L

$=13.2$ Therms/hour ( $\%$ of total $=10.00$ )

Where $\underline{Q}_{H}^{\prime}+Q_{P}^{\prime}=Q_{T}^{\prime}+Q_{-}^{\prime}=132$ Therms/hour

In this example, the Figure-of-Merit (FM) for hot water heating only, defined as gallons of hot water/therm of natural gas is:

$$
F M=\frac{5,026}{64.2}=78.3 \text { gallons of hot water/therm }
$$


B. Based on water consumption for period January 1976 through June 1976 and equipment changes during the perjod June 1975 to December 1975 ,

Estimated 1976 annual wạter consumption

$=23.744 \mathrm{Mg} / \mathrm{yr}$.

$=11,175 \mathrm{gals} / \mathrm{hr}$.

Estirnated 1976 annual hot ivater consumption

$=17.433 \mathrm{Mg} / \mathrm{yr}$.

$=8,381 \mathrm{gals} / \mathrm{hr}$.

Corresponding values for hourly gas consumption, without wastewater heat reclamation or solar heat would theoretically be:

\begin{tabular}{|c|c|c|}
\hline$Q_{H}^{\prime}$ & $=107$ Therms/hour & (\% of total 62.2) \\
\hline$Q_{\mathbf{p}}^{\prime}$ & $=15$ Therms/hour & (\% of total 8.7) \\
\hline$Q_{\text {TD }}^{\prime}$ & $=39$ Therms/hour & (\%. of total 22.7) \\
\hline & $=11$ Therms/hour & ( $\%$ of total 6.4 ) \\
\hline
\end{tabular}

Then $Q_{T}^{\prime}=Q_{H}^{\prime}+Q_{P}^{\prime}+Q_{T D}^{\prime}+Q_{L}^{\prime} \quad \equiv 172$ Therms/hour

and $F M=\underline{8,381}=78,3$ gallons $/$ Therm 107

This value will be used to derive the actual energy savings attributable to the wastewater heat reclaimer, based on data taken during the same period, i.e. January 1.976 through June 1976.

\section{CASE 2 = AUXILIARY SYSTEM WITH WASTEVATER HEAT RECLAMATION}

Estimated 1976 water consumption $=23.244 \mathrm{Mg} / \mathrm{yr} .=11,175 \mathrm{gals} / \mathrm{hr}$.

Estimated 1976 gas consumption $=264,340 \mathrm{Therms} / \mathrm{yr}=127 \mathrm{Thërms} / \mathrm{hr}$.

From Case 1 (B.) above, assuming that the net reduction in energy input due wastewater heat recovery is reflected in reductions in values of $Q_{H}^{\prime}$ only:

$$
\begin{aligned}
Q_{W R}^{\prime} & =\frac{\text { Hot Water flow/hour }(\mathrm{gph}) \times 8.33 \times\left(155-65^{\circ} \mathrm{F}\right)}{\mathrm{g}} \\
& =\frac{8,381 \times 8.33 \times\left(115^{\mathrm{g}}-65\right)}{0.75} .
\end{aligned}
$$

= 46.5 Therms/hour

Since $172 Q_{W R}^{\prime}=125.5$ Therms/hour.

New value of $Q_{H}^{\prime}$ is $107-46.5=60.5$ Therms/hour.

The new value of the Figure-of-Merit (FM) is given by:

$F M=\frac{8,381}{60.5}=138.5$ gallons of hot water/therm. 
From Section 2.0 of this report the nominal energy output from the solar subsystem is $2.0 \times 10^{9} \mathrm{BTU} /$ year.

Equivalent hourly average output

$$
\mathrm{Q}_{\mathrm{S}}=2 \times 10^{9} \times 10^{-5} \text { Therms/hour }
$$

$=9.6$ Ther $\mathrm{ms} /$ hour

Equivalent hourly energy savings, factored for boiler efficiency $(=0.75)$

$$
Q_{S}^{\prime}=12.8 \text { Therins/hour }
$$

i.e. $\quad Q^{n}$ is reduced to $(60.5-12.8)=47.7$ Therms/hour

The Figure-of-Merit for the auxiliary source now becomes:

$$
F M=\frac{8,381}{47.7}=175.7 \text { gallons of hot water/therm. }
$$

The results oi tinis analysis are summarized below in Table $6-1$. It should be emphasized that the results presented are estimates only, based on limited available data. Normal variations in laundry processes and merchandise mix, including seasonal variations, can result in wide variations in diurnal energy demands. These can only. be accurately determined after the installation of adequate instrumentation, to be supplied by. ERDA/NASA as a part of solar demonstration contract. 
TABLE 6-I - COMPARATIVE PERFORMANCE OF HOT WATER

SYSTEM AT RED STAR INDUSTRIAL SERVICE, FRESNO, CALIF.

WITH ALTERNATE CONSERVATION SYSTEMS

\begin{tabular}{|c|c|c|c|}
\hline $\begin{array}{c}\text { SYSTEM } \\
. \\
\end{array}$ & $\begin{array}{l}\text { igure-of- } \\
\text { merit (Gals. } \\
\text { Hot Water/ } \\
\text { Therms } \\
\end{array}$ & $\begin{array}{l}\text { Estimated Energy } \\
\text { Consumption for } \\
\text { Hot Water (Therms) } \\
\text { by Boilex } \\
\end{array}$ & $\begin{array}{c}\text { Estimated Energy } \\
\text { Savings } \\
\text { (Therms) }\end{array}$ \\
\hline 1 Boiler only & $\begin{array}{c}\mathbf{7 8 , 3} \\
\therefore \quad \therefore \quad\end{array}$ & 224.644 & - \\
\hline $\begin{array}{l}\text { Boiler \& Wastewater } \\
\text { Heat Reclamation } \\
\text { Subsystem }\end{array}$ & 138.5 & 125.870 & 98.774 Therms/yr. \\
\hline $\begin{array}{l}\text { Boiler \& Wastewater } \\
\text { Heat Reclamation } \\
\text { and Solar sub- } \\
\text { System }\end{array}$ & 175.7 & 99,220 & 125,424 Therms/Yr. \\
\hline
\end{tabular}




\section{SECTION 6.1.2 SOLAR SUBSYSTEM PERFORMANCE}

Predicted Solar Collector Subsystem performance was originally calculated using the very limited data submitted by Desert Sunshine Exposure Test, Inc., in a letter report dated November 18, 1976. The results are given in Table 6.2. Solar insolation data used in the computation was derived from the NASA/MSFC computer printout provided by Ray Spink at a meeting held in Huntsville, Alabama on September 15, 197.7, factored by $\%$ sunshine data supplied by NOAA. Solar insolation data is reproduced in Table 6.3.

Figure 6.2 shows the predicted efficiency curve for the Ying SP4120 collector with single Lexan III cover and Dunn-Edwards W201-20 Flat Back Coating. "The efficiency curve is superimposed on the NASA Lewis Research Center Solar Simulator data in Figure 6.3:: 
TABLE 6.2 PREDICTED SOIAR COLLECTOR SUBSYSTEM PERFORMANCE

\begin{tabular}{|c|c|c|c|c|c|c|c|c|c|}
\hline MONTH & $\begin{array}{l}\text { Incident Daily } \\
\text { Insolation at } \\
30^{\circ} \text { tilt angle } \\
\left(\mathrm{BTU} / \mathrm{Ft}^{2}\right)\end{array}$ & $\begin{array}{c}\text { Ambient } \\
\text { Temp. } \\
\mathrm{T}_{\mathrm{a}}\end{array}$ & $120-\mathrm{Ta}_{\mathrm{a}}$ & $\Delta T$ & \begin{tabular}{|l|} 
Hourly \\
Avg. In- \\
solation \\
$Q\left(B T U / F t^{2}\right)$
\end{tabular} & $\begin{array}{l}\text { Fluid } \\
\text { Factor } \\
\Delta \mathrm{T} G\end{array}$ & $\eta$ & $\begin{array}{c}\% \text { of } \\
\text { sun- } \\
\text { shine } \\
\mathrm{P} \\
\end{array}$ & $\begin{array}{l}\text { Net Daily } \\
\text { Insolation } \\
\bar{I}=\text { IXyx P) } \\
\text { BTU/Ft2 }\end{array}$ \\
\hline JAN & 1750 & 50 & 70 & 73 & 260 & C. 280 & 0.52 & 46 & 418.6 \\
\hline$F E B$ & 2076 & 60 & 60 & 65 & 275 & 0.236 & 0.56 & 63 & 732.4 \\
\hline MAR & 2291 & 75 & 55 & 62 & 305 & 0.203 & 0.58 & 72 & 956.7 \\
\hline$A P R$ & 2321 & 85 & 35 & 45 & 305 & 0.148 & 0.63 & 83 & 1213.7 \\
\hline MAY & 2269 & 90 & 30 & 40 & 300 & 0.133 & 0.64 & 89 & 1292.4 \\
\hline$\pi U N$ & 2225 & 95 & 25 & 37 & 290 & 0.128 & 0.65 & 96 & 1388.4 \\
\hline JUL & 2228 & 95 & 25 & 37 & 290 & 0.128 & 0.65 & 96 & 1390.7 \\
\hline AUG & $2238 *$ & 90 & 30 & 40 & 300 & 0.133 & 0.64 & 89 & 1274.8 \\
\hline SEP & 2190 & 85 & 35 & 45 & 305 & 0.148 & 0.63 & 83 & 1145.1 \\
\hline OCT & 1992 & 75 & $45 * 3$ & $54 * \xi$ & 305 & 0.203 & 0.58 & 72 & 831.9 \\
\hline NOV & 1712 & 60 & 60 & 65 & 275 & 0.236 & 0.56 & 63 & 604.0 \\
\hline$D E C$ & 1595 & 50 & 70 & 73 & 260 & 0.280 & 0.52 & 46 & 381.5 \\
\hline & & & & & & & \multicolumn{2}{|c|}{ SUB-TOTAL } & 11.630 .2 \\
\hline
\end{tabular}

Annual Energy Output/Square Foot $=\frac{11,630.2 \times 365}{12} \mathrm{BTU} / \mathrm{Ft}^{2}$

Net Array area A

$\therefore$ Total Energy Output Less $10 \%$ losses
$=353,752 \mathrm{BTU} / \mathrm{Ft}^{2}$

$=6.280 \mathrm{Ft}^{2}$
$=2.222 \times 10^{9} \mathrm{BTU} /$ year
$=2.0 \times 1.09 \mathrm{BTU} /$ year

Notes:. 1. Insolation data from NASA-MSFC - computer Print-out dated 9/15/76

2. \% Sunshine data from NOAA Fresno, California

3. Efficiency ( $y$ ) based on DSET data 
PACE 2 OF 1

IHSOLAYION YALUES INCLUDE DIREGY AND DIFFUSE COMPONENIS EXCEPT FOR O.CO VALUES

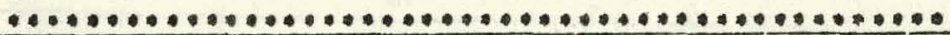

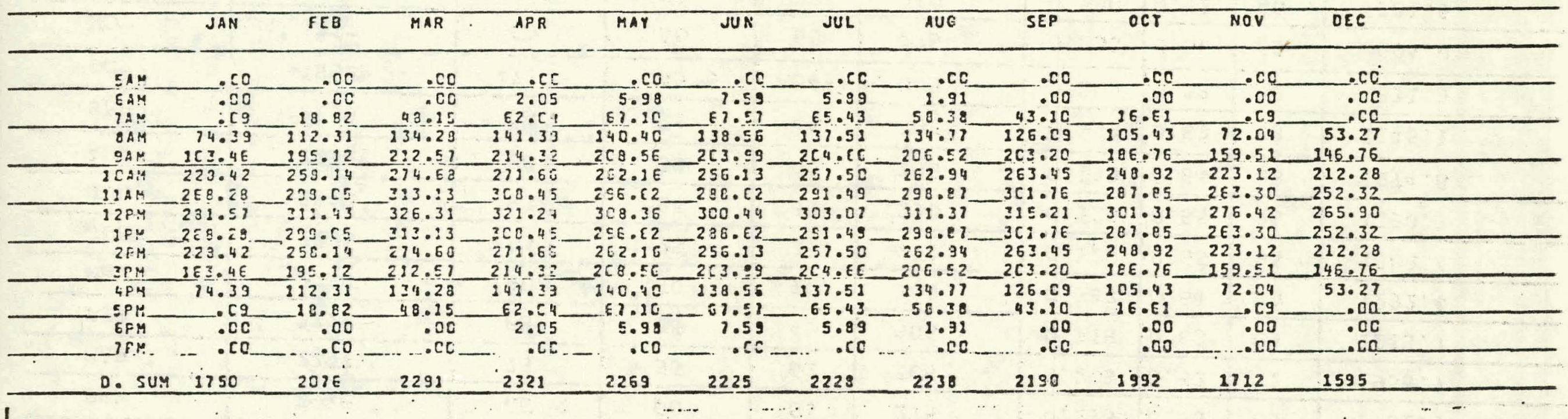


FIGURE 6.2

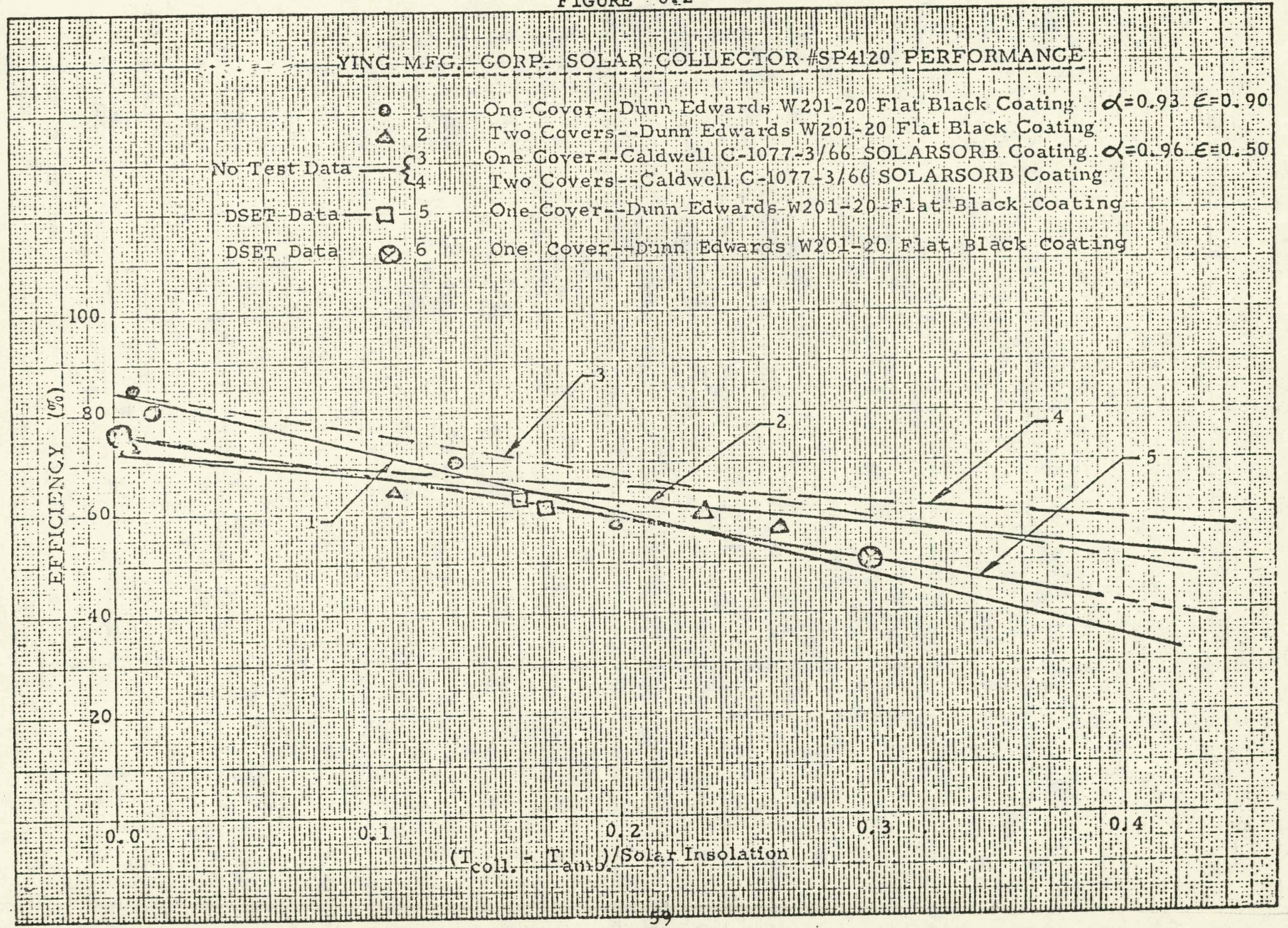




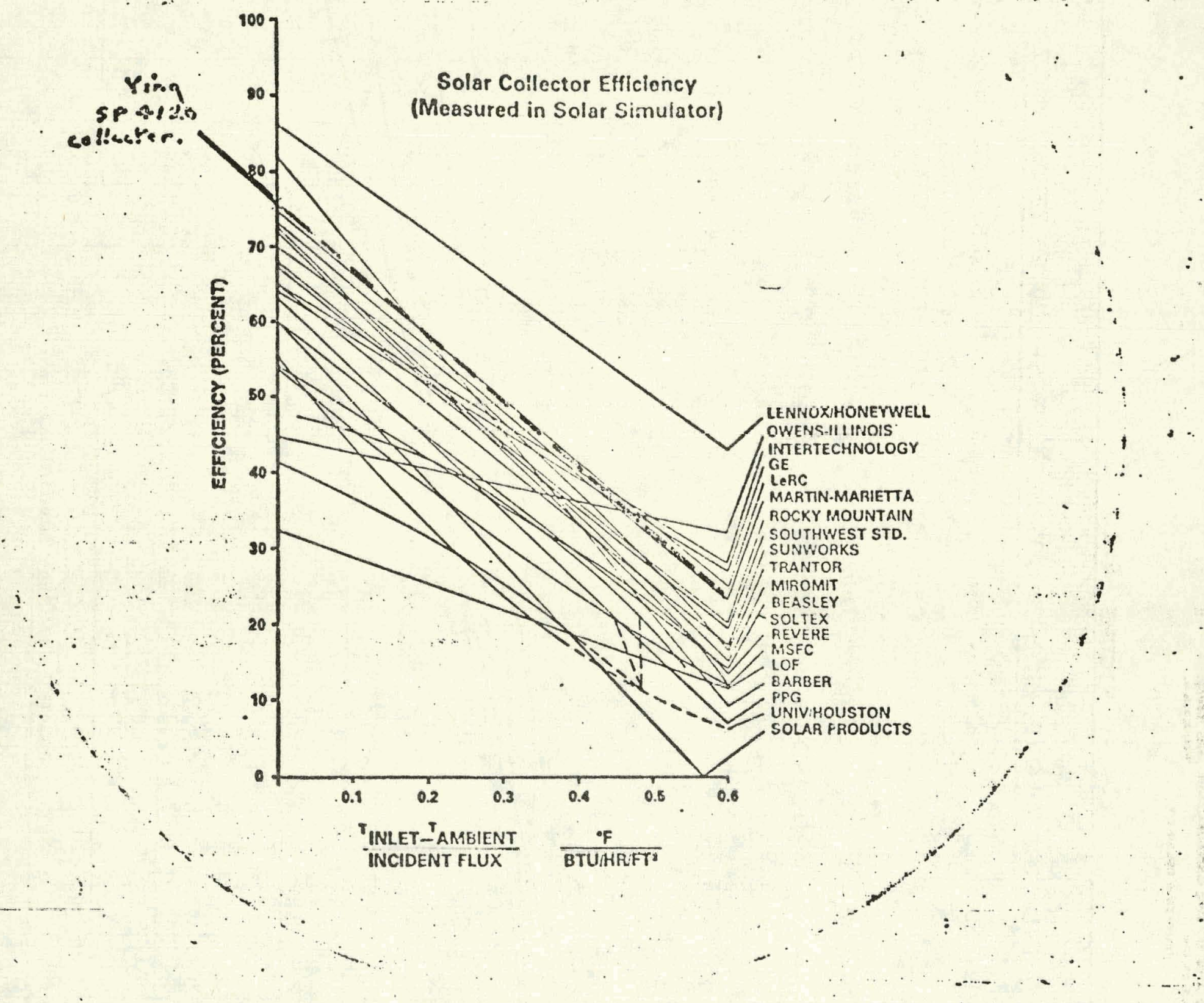

(Ying SP4120 Single Glazed Collector data superimposed for comparison, based on latest Desert Sunshine test data)

References: 1 NASA Lewis Research Center Technical Memorandum NASA TMX-71793 dated 7/28/76 entitled "Flat-plate Solar collector Performance Evaluation with a Solar simulator as a basis for collector Selection \& Performance prediction".

2 Diagram reproduced from Appliance Manufacturer, November 1976.

3 Ying Sp4l20 Efficiency Curve based on Desert Sunshine test in December 1975. 


\section{SECTION 6.2 COMPUTED DATA FOR PERIOD FROM MARCH TO MAY 1978}

Data, derived from the D.O.E. report entitled "Solar Energy System Performance Evaluation; Fresno, California: - November 1977 through May 1978", authored by Henry L: Armstrong, et al. of IBM is repeated, together with more recent data for the months of June, July and August 1978, extracted from the National Solar Data Program Monthly Performance Reports.

TABLE IV - 2.1

\section{THERMAL PERFORMANCE WITH HEAT RECOVERY ENERGY}

\begin{tabular}{|c|c|c|c|c|c|c|}
\hline MONTH & $\begin{array}{c}\text { Total System } \\
\text { Load* } \\
\text { (Million BTU) }\end{array}$ & \begin{tabular}{l}
\multicolumn{1}{c}{ Energy } \\
Supplied By \\
Heat Recovery \\
(Million BTU) \\
\end{tabular} & \begin{tabular}{l}
\multicolumn{1}{c}{ Energy } \\
Supplied By \\
Solar System \\
(Million BTU) \\
\end{tabular} & $\begin{array}{l}\text { Energy } \\
\text { Supplied By } \\
\text { Aux. System } \\
\text { (Million BTU) }\end{array}$ & $\begin{array}{c}\text { Solar } \\
\text { Fraction } \\
\underline{\%}\end{array}$ & $\begin{array}{l}\text { Fossil Savings } \\
\text { (Solar Only) } \\
\text { (Million BTU) }\end{array}$ \\
\hline March 1978 & 562 & 225 & 52 & 285 & 16 & 87 \\
\hline April 1978 & 490 & 182 & 59 & 249 & 19 & 99 \\
\hline May 1978 & 526 & 200 & 77 & 248 & 24 & 76 \\
\hline June 1978 & 411 & 190 & 99 & 304 & 24 & 165 \\
\hline July 1978 & 408 & 172 & 113 & 285 & 28 & 189 \\
\hline August 1978 & 435 & 203 & $109:$ & 320 & 25 & 181 \\
\hline
\end{tabular}

Analysis of water bills and IBM data for recent months indicates that an average of 36,000 gpd of hot water was used in the facility during the period under review. It was similarily. determined from gas meter readings that the total auxiliary load for hot water supply was somewhat higher than the IBM data would indicate. 
For comparison, calculated data for the six month period was averaged to give the following results, based on an assumed boiler efficiency of $60 \%$.

Total Hot Water Load including Heat Recovery \& 10\% Losises

Heat Recovery System (HRS') Input

Hot Water Load excluding Heat Recovery

Solar Input

Auxiliary Energy Supplied

Auxiliary Fossil Fuel

Fossil Energy Savings (HRS' Only)

Fossil Energy Savings (Solar)

Total Fossil Fuel Use without (HRS' or Solar)

x Savings duc to HR S'

\% Savings due to Solar
$640 \times 10^{6} \mathrm{BTU} / \mathrm{month}$. $188 \times 10^{6}$. BTU/month. $490 \times 10^{6}$ BTU $/$ month $107 \times 10^{6} \mathrm{BTU} /$ month - $\quad 345 \times 10^{6} \mathrm{BTU} / \mathrm{month}$ $575 \times 10^{6} \mathrm{BTU} /$ month $313 \times 10^{6} \mathrm{BTU} / \mathrm{month}$ $178 \times 10^{6} \mathrm{BTU} / \mathrm{month}$ $1,066 \times 10^{6} \mathrm{BTU} / \mathrm{month}$ $29 \%$ $17 \%$

Deriving the Figure-of-Merit (Gallons of Hot Water/Therm of Natural Gas or equivalent). the following figures are obtained:

\section{System}

BOII.ER. ONI.Y

BOILER \& HRS'

BOILER, HRS' \& SOLAR

\section{Computed Figure-of-Merit} (Hot Water/Therm)

72.6

103

135

\section{Predicted Figure-of-Merit} (Hot Water/Therm)

78.3

138.5

175.7

More accurate data from the National Solar Data Program in the coming months should enable these figures to be refined. It is, however, apparent that there is a significant loss in the efficiency of the Solar Subsystem for reasons previously stated, and also a loss of 6\% to $10 \%$ in Wastewater Heat Recovery Subsystem efficicricy compared with predicted performance. The latter is partly attributable to greater use of low temperature washroom processes, reflecting in lower than optimum U-values in the heat exchanger.

NOTE: HRS' - Wastewater Heat Recovery Subsystem 
At the present cost (as of March. 1980) of natural gas in California (\$4.043/McF), annual savings are estimated at:

Wastewater Heat Recovery Subsystem

Solar Subsystem
$\$ 15,187.00$

$3,516.00$

$. \$ 18,703.00$ per annum

FOOTNOTE: Assumptions made in deriving the Figures-of-Merit quoted above were as follows:

- Gas consumption for Boiler - 65\% of total gas consumed

- Steam for water heating - $50 \%$ of total steam

- Gas consumption (Total) 23,000 Therms/mo:

- Water consumption (Total) 774,000 Gallons/mo,

- Hot Water consumption-50\% of total water used

- Boiler Efficiency (per IBM) - 60\%

- Incoming Water Tempcrature (Average) $-75^{\circ} \mathrm{F}$.

- Outgoing Water Temperature (Average) - $172^{\circ} \mathrm{F}$. 
THIS PAGE

\section{WAS INTENTIONALLY LEFT BLANK}




\section{SECTION 7.0 MAJOR PROBLEMS}

Initially, immediately following award of the contract, it appeared that the whole project would be in jeopardy due to a disagreement between ERDA (now DOE) and ARATEX (formerly Work Wear Corporation) with respect to the required level of funding. This problem was only resolved after the California State Energy Resources Conservation and Development Commission (now the California Energy Commission) agreed to provide additional funding in the amount of $\$ 17,000.00$, to supplement the DOE grant of $\$ 165,000.00$

A further factor contributing to the initial delay in actually starting fabrication and construction on the project was the difficulty in selecting a solar collector contractor who could provide the necessary performance data, and could guarantee delivery of the number of panels required for this installation. The problem was further compounded by the realization that a lightweight panel would be required if the structural limitations, inherent in the design of the building, were to be overcome. This problem is discussed below in Section 7.1.

The time from submittal of the proposal in response to PON-1 to the signing of the sub-contracts was almost one year. Thereafter, work proceeded smoothly on the project and the system first went on line in July 1977. These and other minor problems are discussed in the following sub-sections of this report.

\section{SECTION 7.1 SOLAR COLLECTOR SELECTION}

After it became apparent that the solar collector designer who had been originally named in the proposal, Truman Temple and Associates, did not have the production capability to manufacture the required number of panels; other contractors were approáched for quotations. Negotiations with one of the potential contractors, Piper Hydro, Inc., were terminated when it became apparent that performance data relating to the Piper Hydro collectors was not going to be made available to ARATEX Services, Inc. At the same time, following stress analysis of the roof structure in Fresno, it became apparent that a roof loading of no more than two (2) pounds per square foot attributable to the solar collectors would have to be realized, if additional structure modifications to the roof were to be avoided. This limitation, together with a lack of performance data, eliminated many of the potential contractors, leaving Ying Manufacturing Corporation as the only contractor capable of meeting the requirements of this particular project. This was considered to be a major break-through in the initiation of the project hardware phase, notwithstanding the fact that very limited performance data was available at this time (November 1976). 


\section{SECTION 7.2 STRUCTURAL PROBLEMS}

Configuration studies and stress analysis had revealed the criticality of roof loading at the $\ddot{F}$ resno site. After resurfacing the roof (a necessary pre-requisite to installation of the solar array), available roof loading for the solar array was limited to approximately 2.5 pounds per square foot. Because this loading factor was considered to be marginal, the decision was made to reduce the amount of gravel actually applied to the roof during the resurfacing operation.

A further problem which arose during the construction phase was the difficulty encountered in sealing the attachment bolts whlch secured the supporting framework for the solar collectors to the roof. This has resulted in some roof leaks during the rainy season, which are a serious problem in this particular facility because of potential damage to the many garments being processed and stored beneath the roof area. Corrective action is presently being taken to overcorne this problem.

These problems underscored the difficulty of retrofitting a large solar installation to an existing structure.

\section{SECTION 7.3 STAGNATION CONDITIONS}

Af ter installation of the solar collectors in April 1976, the collectors were allowed to stagnate with no fluid in the collectors and no protective covers. This resulted in collector temperatures of $400^{\circ} \mathrm{F}$, with resultant damage to the selective coating and to the glazing which only became apparent after the system had been put into operation and formally dedicated in September 1977. Priur to this timc, there was no apparent damage. However, it has now become apparent that there is quitc a serious loss in performance attributable to the damage incurred during the stagnation period, exacerbated by unusually adverse weather conditions during the winter of 1976/77. Supplemental funding was requested from D.O.E. to rectify this problern, which was initially denied. Subsequently, $\$ 11,000.00$ was made available to the project, cnabling the contractor to remove ninety (90) of the collector panels for re-surfacing, replacement of the damaged Lexan glazing with Tedlar, and re-installation of the collectors. If sufficient additional funding is made available by D.O.E., the remaining fifty $(50)$ pancls will be reworked. Due to climatic conditions in Fresno, this work will have to be performed in the late Fall of 1980, or Spring of 1981 . 


\section{SECTION 7.4 DUST ACCRETION}

While low relative humidity and agricultural activities in the Fresno area result in high dust concentrations in the atmosphere during the summer months, the amount of dust which collects on the Lexan covers of the solar collectors appears to be excessive. This results in a requirement to clean the panels with water and a non-ionic detergent every week. This is considered to be an unacceptable maintenance burden $n$ n the facility. A possible mechanism for this excessive dust accumulation would appear to be electrostatic attraction, due to : the fact that the panels are electrically insulated from a ground plane by the connecting hoses between the header and return lines. Once again, supplemental funding to investigate and solve this problem has so far been denied by D.O.E. This phenomena is believed to contribute to some of the degradation in performance which has been observed, based on the latest IBM data.

\section{SECTION 7.5. ALARM AND DISPLAY SYSTEMS}

During the integration and test phase of the solar sub-system, it was determined that there was one particular failure mode which could result in a potentially dangerous: condition, which could go unnoticed without observation of the control panel light indicators. This arose because of the requirement that a common-control voltage be used for controlling not only the solar sub-system functions, but also the auxiliary hot water storage tank level control functions in the boiler room. Accordingly, it was decided to put in an auxiliary relay and alarm circuit to provide warning of a loss of control vol tage to the operators in the boiler room. At the same time, additional alarms were added to the system. - including both visual and audible indicators - to provide for a warning in the event of the failure of any of the pumps in the system. While these alarms monitor non-critical functions, they do serve as diagnostic tools in the event of a failure of any of the pump circuits. 


\section{SECTION 7.6 CONSTANT FLOW REGULATORS}

During evaluation of the initial systems design, it was determined that each of the 140 . solar collector panels would require an independent constant flow regulator to ensure that the flow rate through each panel was optimized at $2 \mathrm{gpm}$. Unfortunately, the type of flow regulator chosen proved to have excessive head loss at the required flow rate. Modifications to the units resulted in a reduction of the back-pressure to 2 psi, which was considered to be acceptable, notwithstanding the fact that this resulted in a requirement to operate. both circulating pumps to attain the desired flow. Since the initiation of this project, better flow regulators with a lower head loss have become available and would be used in future installations.

\section{SECTION 7.7 IBM INSTRUMENTATION AND PERFORMANCE DATA}

Recurrent difficulties with the sensors chosen for this project and the need to replace many of the sensors has resulted in many delays in obtaining reliable data. As late as August 1978 sensors were still being replaced and calibrated. In consequence, it would appear that the earliest data upon any reliance could be placed, for purposes of system performance assessment, is the data which was-accumulated during the month of September 1978. Since this problem has been common; to many of the DOE Solar Energy projects, there is no need to elaborate further on this problem.

\section{SECTION 7.8 PROGRAM MANAGEMENT}

The level of effort required to satisfy contractual requirements - both financial and in terms of man-power - was grossly underestimated at the start of this project. Specifically, man-power and financial cornmittments to program management were significantly greater than had been expected, while the continuing demands for non-contractual involvement in other related DOE programs has resulted in significant expenditure of effort in order to meet these requirements. This problem essentially precludes small companies from taking part in the PON programs, since smaller companies cannot afford the man-power and costs related to the contractual and non-contractual requirements of such programs. 


\section{SECTION 8.0}

\section{LESSONS LEARNED AND RECOMMENDATIONS}




\section{SECTION 8.0 LESSONS LEARNED AND RECOIMAIENDATIONS}

In retrospect, it is unlikely that a commercial organization such as ARATEX Services, Inc. (formerly Work Wear Corporation) would embark on a project of this magnitude without a better definition of the contractual and cost requirements for such a program. Bearing in mind the very low return on investment of such programs, it is unlikely that Corporate management could be induced to embark on similar programs unless more flexible financial arrangements could be set up at the start of the project. There is little incentive to embark on high-risk projects without improved financial incentives.

Many of the frustrations on this project were - and still are - related to the method of monitoring the project and providing information to enable the contractor to assess the performance of the system in order to take whatever corrective action may be required to improve system performance. Furthermore, the cost of providing additional instrumentation for use by the contractor was not reflected in the fixed cost of the project when the initial negotiations took place. It is recommended that either additional funds be allocated to the project for on-site instrumentation, or better arrangements be made with the data analysis group, to provide data in a timely fashion to the contractor.

"Out of Sight - Out of Mind" is a characteristic of solar energy projects. Solar systems for industrial applications need to be fully automated, with adequate allowance provided to prevent catastrophic failure. More attention also nceds to be paid to the problem of. maintaining performance through routine cleaning procedures for the solar collectors. This problem has been grossly underestimated in many projects.

Finally, there is a need on the part of DOE to recognize that, in the commercial world, "Time is Money". If follow-up activities by DOE sponsored contractors and laboratories are required, then compensation should be provided to the prime contractor for time spent in supporting these activities. 


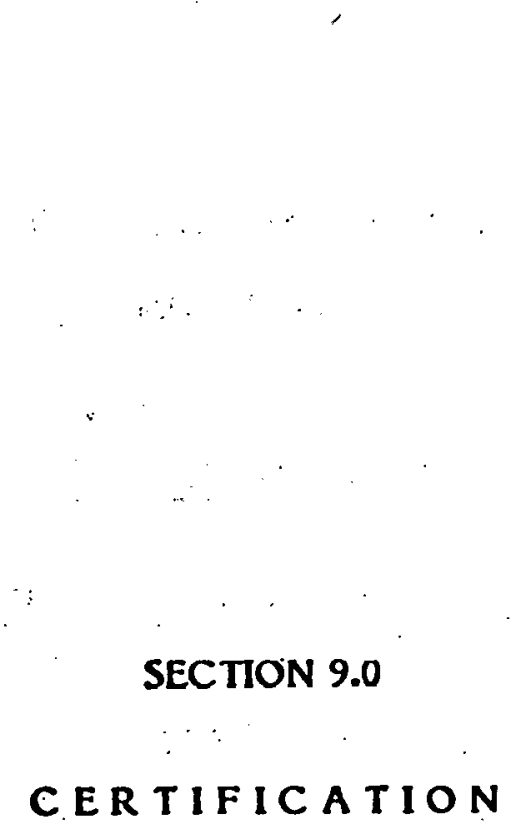

C.ER TIFICATION 


\section{INTERIM PERFORMANCE CRITERIA}

CERTIFICATION

CONTRACT NUMBER

EX-76-C-01-2384

DEMONSTRATION CONTRACTTŌR ARATEX Services, Inc. (Formerly Wurk Wear Corporation)

SYSTEM LOCATION

SYSTEM TYPE
Fresno, Calitornia

Hot Water (Industrial Laundry)

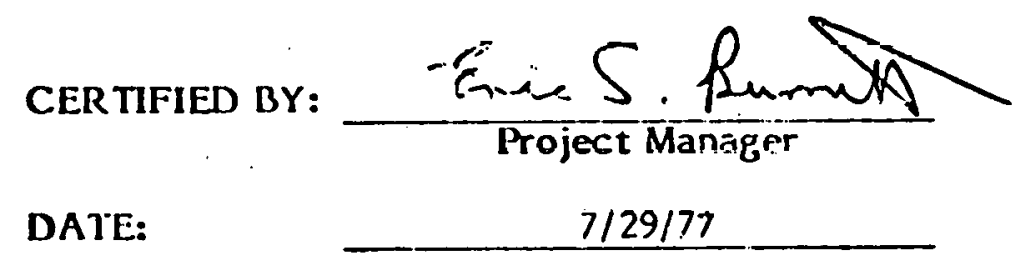




\section{APPENDIX A

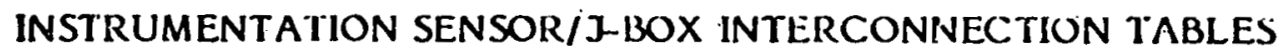


APPENDIX A - Instrmentarien Sensor/J-Le Interconnections Tables

Site: ARATEX/Red Stä

\begin{tabular}{|c|c|c|c|c|c|c|}
\hline$F R O M$ & $S E N S O R$ & T 0 & J U N C T & $I \circ N$ & B $O X$ & \\
\hline $\begin{array}{c}\text { Sensor } \\
\text { Number }\end{array}$ & $\begin{array}{l}\text { Sensor } \\
\text { Connection } \\
/ \text { Colox }\end{array}$ & $\begin{array}{l}\text { Sensor } / J-\text { Box } \\
\text { Wire Color }\end{array}$ & $\begin{array}{c}\text { External } \\
\text { Cable Number }\end{array}$ & $\begin{array}{c}\text { Terminal } \\
\text { Strip Number }\end{array}$ & $\begin{array}{c}\text { SDAS } \\
\text { Channel }\end{array}$ & Level \\
\hline T001 & $\mathbf{R}$ & $\mathbf{R}$ & $\$ 33$ & TB6-1 & 16 & \\
\hline$"$ & $W *$ & B ..: & $"$ & TB6-2 & 16 & \\
\hline$"$ & $W^{*}$ & c & 1 & TB6-4 & 16 & \\
\hline 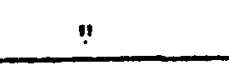 & & $s$ & $"$ & $T B 6-3$ & & $s$ \\
\hline.$T 100$ & $\mathbf{R}$ & $\mathrm{R}$ & \# 9 & T'B4-11 & 12 & \\
\hline 1 & $w^{*}$ & B & $"$ & TB4-12 & 12 & \\
\hline$"$ & $W^{*}$ & c & $n$ & TB4-14 & 12 & \\
\hline$"$ & & $s$ & - & TB4-13 & & $s$ \\
\hline $\mathrm{T} 150$ & $\Omega$ & $\mathrm{R}$ & 㭋1 & TB5-6 & 14 & \\
\hline$"$ & $W^{*}$ & $B$ & 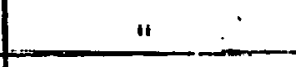 & $M B J-7$ & 14 & \\
\hline$"$ & $W^{*}$ & C & "1 & TB5-9 & 14 & \\
\hline$"$ & & $s$ & & $T B 5-8$ & & $s$ \\
\hline T101 & $\underline{R}$ & R & $\# 12$ & TE8-6 & 23 & \\
\hline$"$ & $n^{*}$ & $\mathrm{~B}$ & " & $T B 8=14$ & 23 & \\
\hline$"$ & $W^{*}$ & C & 1 & TB8-7 & 23 & \\
\hline$"$ & & $s$ & & TB8-8 & & $\underline{s}$ \\
\hline T.151 & $\underline{R}$ & $B$ & 坓26 & $T B 6-11$ & 28 & \\
\hline$"$ & $W^{*}$ & $B$ & $"$ & TB6-12 & 18 & \\
\hline$"$ & $w^{*}$ & c & $"$ & TB6-14 & 18 & \\
\hline$"$ & & $\mathbf{s}$ & & $136-13$ & & $\underline{S}$ \\
\hline $\mathrm{T} 102$ & $Y^{*}$ & $\underline{R}$ & 非34 & TB3-11 & 9 & \\
\hline$"$ & $Y *$ & B & $"$ & TB3-12 & 9 & \\
\hline 1 & $\star \star$ & $c$ & $"$ & $T B 3-10$ & 9 & \\
\hline$"$ & & s & $"$ & TB3-13 & & $\mathbf{S}$ \\
\hline $\mathrm{T} 200$ & R & $\underline{R}$ & $\# 15$ & TB7-6 & 20 & \\
\hline$\because$ & $W^{\star}$ & $B$ & $"$ & TB7-7 & 20 & \\
\hline$"$ & $W^{*}$ & C & $"$ & T. $7-9$ & 20 & \\
\hline$"$ & & $s$ & & TB7-8 & & $s$ \\
\hline 3.201 & $\mathrm{R}$ & R & H14 & TB9-6 & 26 & \\
\hline$"$ & wt & $B$ & $\because$ & $T 32-7$ & 26 & \\
\hline$"$ & $W^{\star}$ & $c$ & $"$ & TB9-9 & 26 & \\
\hline
\end{tabular}
Wire List 7933721 Page: 1 of

Wire Color Code: $\underline{\mathrm{B}}=$ Black, $\underline{C}=$ clear, $\underline{R}=$ Red, $\underline{S}=$ shield, $\frac{W}{7}=$ White, $\underline{Y}=$ Yellow. NOT'E: $*=$ Either Wire 
APPENDIX A - Instrumentation Sensor/J-Box Interconnections Tables

Site: ARATEX/Red Stax

\begin{tabular}{|c|c|c|c|}
\hline$R O M$ & $S E N S O R$ & To & $\mathbf{J} \cup \mathbf{N} C \mathbf{T}$ \\
\hline $\begin{array}{c}\text { Sensor } \\
\text { Number } \\
\end{array}$ & $\mid \begin{array}{c}\text { Sensor } \\
\text { Connection } \\
\text { Color }\end{array}$ & $\begin{array}{l}\text { Sensor/J-Box } \\
\text { Wire Color }\end{array}$ & $\begin{array}{c}\text { External } \\
\text { Cable Number }\end{array}$ \\
\hline $\mathrm{T} 201$ & & $\mathrm{~s}$ & \\
\hline $\mathrm{T} 202$ & $\mathbf{R}$ & $\mathbf{R}$ & $\# 12$ \\
\hline$"$ & $W^{*}$ & B & $"$ \\
\hline$"$ & $W^{*}$ & c & $"$ \\
\hline$"$ & & $\mathbf{s}$ & \\
\hline T300 & $R$ & $\mathrm{R}$ & $\# 7$ \\
\hline$"$ & $W^{*}$ & B & $"$ \\
\hline$"$ & $W^{*}$ & C & $\cdot$ \\
\hline$"$ & & 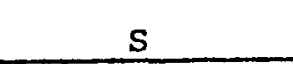 & \\
\hline T350 & $W^{*}$ & B & $\# 8$ \\
\hline$"$ & $W^{*}$ & $\mathrm{C}$ & $"$ \\
\hline$"$ & - & R & $"$ \\
\hline$"$ & & $s$ & \\
\hline T35. & R & $\mathbf{R}$ & 非51 \\
\hline$"$ & $W^{*}$ & $B$ & $"$ \\
\hline$"$ & $\mathrm{~W}^{*}$ & $\mathrm{C}$ & $"$ \\
\hline$"$ & & s & \\
\hline $\mathrm{T} 302$ & $\underline{R}$ & $\underline{R}$ & \#52 \\
\hline$"$ & $W^{*}$ & B & $"$ \\
\hline$"$ & $W^{*}$ & $c$ & $"$ \\
\hline$"$ & & $S$ & \\
\hline T352 & $\mathrm{R}$ & $\underline{R}$ & \#54 \\
\hline$"$ & $W^{*}$ & $\mathrm{~B}$ & $"$ \\
\hline$"$ & $\mathrm{~W}^{*}$ & C & " \\
\hline$"$ & & $\underline{s}$ & \\
\hline T303 & R & $R$ & $\$ 25$ \\
\hline$"$ & $W^{*}$ & B & $"$ \\
\hline 1 & $W^{*}$ & C & $"$ \\
\hline$"$ & & $s$ & \\
\hline T304 & R & $\mathrm{R}$ & 少 23 \\
\hline$"$ & $n^{*}$ & $\mathrm{~B}$ & II \\
\hline
\end{tabular}

Page: 2 of 4

B O X

Terminal SDAS
Strip Number Channel

Levë̀\begin{tabular}{l|l|l} 
TB9-8 & & $\vdots \mathrm{S}$ \\
\hline
\end{tabular}

\begin{tabular}{l|r} 
TB10-1 & 28 \\
\hline
\end{tabular}

\begin{tabular}{l|r} 
TB10-2 & 28 \\
\hline
\end{tabular} \begin{tabular}{l|l} 
TB10-4 & 28 \\
\hline
\end{tabular} TB10-3 IB $3-6$ TB3-7 TB3-9

TB 3-8

$x+31-7$ \begin{tabular}{l|l}
$\mathrm{I} B \mathrm{~B} 1-9$ & 02 \\
\hline
\end{tabular}

$\operatorname{Ts} 1-6$

TR $3-8$

$T B 2-1$

$T \mathrm{~B}^{2} 2$

TB2-4

$T_{B} 2-3$

IBII-6

TB.11-7

32

TBII-9

TBIl-8

ग!B2-11 6

TB2-12 6

TR2-14 6

TB2-13

IR10-11 30

TB10-12 30

TB10-14 30

TB10-13

TBA-1

\begin{tabular}{l|l} 
IB:-2 & 10 \\
\hline
\end{tabular}

Color Code: $\underline{B}=$ Black, $\underline{C}=$ clear, $\underline{R}=$ Red, $\underline{S}=$ shield, $\underline{W}=$ white, $\underline{Y}=$ Yellow.

NOTE: $\star=$ Either wire

$* *=$ Yollow. Black \& Cleax Connected 
Site: ARATEX/Red Star

\begin{tabular}{|c|c|c|c|c|c|c|}
\hline$F R \circ M$ & $S E N S O R$ & To & $\mathbf{J} \cdot \mathbf{U} \mathbf{N} C \mathrm{~T}$ & $\mathrm{ION}$ & B o $x$ & \\
\hline $\begin{array}{c}\text { Sensor } \\
\text { Number } \\
.\end{array}$ & $\begin{array}{c}\text { Sensor } \\
\text { Connection } \\
/ \text { Color }\end{array}$ & $\begin{array}{l}\text { Sensor/J-Box } \\
\text { Wire Color }\end{array}$ & $\begin{array}{c}\text { External } \\
\text { Cable Number }\end{array}$ & $\begin{array}{c}\text { Terminal } \\
\text { Strip Number }\end{array}$ & $\begin{array}{c}\text { SDAS: } \\
\text { Channel }\end{array}$ & Level \\
\hline - T304 & $w^{*}$ & C & $\# 23$ & TB4-4 & 10 & \\
\hline . & & S . & & TB4-3 & & $\underline{s}$ \\
\hline T354 & $\underline{R}$ & $\mathrm{R}$ & $\# 26$ & TB8-1 & 22 & \\
\hline ." & . $W^{*}$ & B & $"$ & TB8-2 & 22 & \\
\hline$\because$ & $W^{*}$ & $\dot{C}$ & 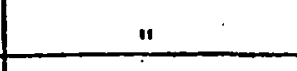 & $\pi \mathrm{R} 8-4$ & 22 & \\
\hline$"$ & & $s$ & 1 & TB8-3 & & $S$ \\
\hline W100 & 1 & $\underline{R}$ & $\$ 21$ & TR4-in & 11. & $+5 \mathrm{VDC}$ \\
\hline$n$ & 2 & C & $"$ & TBA-7 & 11 & $\mathrm{Hi}$ \\
\hline$"$ & 3 & $B$ & $"$ & TR4- & 11 & Iي \\
\hline " & 4 & B & $\# 22$ & TB4-y & i1 & Ground \\
\hline$"$ & & s & & TB4-8 & & $\underline{s}$ \\
\hline W300. & 1 & $\underline{R}$ & \#19 & $T B 1-15$ & 3 & $+5 \mathrm{VDC}$ \\
\hline$"$ & 2 & c & $"$ & $x B l-12$ & 3 & $\mathrm{IIi}$ \\
\hline :" & 3 & B & $"$ & TBI-11 & 3 & Io \\
\hline$\ldots$ & 4 & $B$ & $\$ 20$ & $T B=14$ & 3. & Ground" \\
\hline$"$ & & $\mathrm{~s}$ & & $\mathrm{~TB} 1-13$ & & $\dot{s}$ \\
\hline W301 & 1 & $\underline{R}$ & $\# 56$ & TB2-10 & 5 & $+5 \mathrm{VDC}$ \\
\hline$"$ & 2 & c. & $"$ & $I B 2-7$ & 5 & $\mathrm{Hi}$ \\
\hline$"$ & 3 & $B$ & $n$ & $T B 2-6$ & 5 & عI \\
\hline$\because$ & 4 & B & $\# 57^{\circ}$ & TB2-9 & 5 & Ground \\
\hline$"$ & & $s$ & & TB2-6 & & s \\
\hline W302 & 3 & $B$ & 丮 $55^{\circ}$ & TB9-11 & 27 & \\
\hline$"$ & 2 & W & .1t53 & TB9-12 & 27 & \\
\hline$"$ & & $\mathrm{~s}$ & & TB9-13 & & $s$ \\
\hline$"$ & 4 & $B$ & \#53 & TBa-14 & 27 & , \\
\hline$\therefore$ & 1 & $\mathrm{R}$ & $"$ & TB9-15 & 27 & \\
\hline W303 & 3 & B & $\| 10^{\circ}$ & TR11-1 & 31 & \\
\hline$"$ & 2 & $w$ & 韭18 & IBI $1-2$ & 31 & \\
\hline$"$ & & $S$ & & TB11-3 & & \\
\hline$"$ & 4 & $B$ & 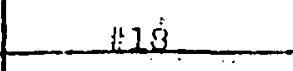 & $\mathrm{TB} \perp 2-4$ & 31 & \\
\hline$"$ & 1 & $\bar{n}$ & $\because$ & TBII-5 & 32 & \\
\hline
\end{tabular}
Wire List: 7933721 
APPENDIX A - Instrumentation Sensor/J-Box Interconnections Tables

Site: ARATEX/Red Star

T ROM SE N S O R

\begin{tabular}{c|c|}
\hline $\begin{array}{c}\text { Sensor } \\
\text { Number }\end{array}$ & $\begin{array}{c}\text { Sensor } \\
\text { Connection } \\
\text { Color }\end{array}$ \\
\hline
\end{tabular}

EP101

II

II

EP301

11

t!

$\mathrm{EP} 302$

\begin{tabular}{l|l}
1 & 2 \\
\hline
\end{tabular}

n

EP 303

11

11

EP304

11

॥

I001

I

11

D001

it

11

in

,

V001

"1

ii

1

2

F

-

B
Wire List: 7933721

I

Sensor/J-Box
wire Color

B

R

S

B

$\mathrm{R}$

s

$B$

R

S

B

R

$\mathrm{S}$

B

R

$\mathrm{S}$

B

R

$\mathrm{S}$

$\mathrm{R}$

C

B

F

I $S$

$\mathrm{A} \quad \mathrm{R}$

B

S

s

Page: 4 of 1

J U N C T I $-N$

B O X

\begin{tabular}{|c|c|}
\hline External & Terminal \\
Cable Number & strip Number
\end{tabular}

SDAS

Channel

Level

\begin{tabular}{|c|c|c}
\hline $\mathrm{B}$ & \#27 & \\
\hline $\mathrm{R}$ & " &
\end{tabular}

TB9-1

TB9-2

25

Io

TB9-3

T'B5-1

TB 5-2

TB5-3

TRK- 6

TB6-7

TBG-8

TB7-1

25

Hi

S

\#28

TB7-2

TB7-3

T87-11

TB7-12

TB7-13

TB3-1

TB3-2

TB3-3

13

13

$\mathrm{Hi}$

s

\#35

"

\begin{tabular}{|c|}
\hline 136 \\
\hline$"$ \\
\hline$"$ \\
\hline$"$
\end{tabular}

TB5-15

TB5-12

TB5-1]

TB5-14

TB5-13

T'B10-7

TB10-6

TB10-8

17

17

Hi

S

Lo

Hi

S

Lo

$\mathrm{Hi}$

$\mathrm{s}$

Lo

Hi

$\mathbf{s}$

$+5 \mathrm{VDC}$

$\mathrm{Hi}$

15

Hi

Lo

Ground

S

$\# 37$

"

TB10-8

(1)

Wire

Color Codc: $\underline{B}=$ slack, $\underline{C}=$ clear,$\underline{R}=$ Red, $\underline{S}=$ shield, $\underline{W}=$ White, $\underline{y}=$ Yellow.

NOTE:

$\star=$ Either Wire

* = Yellonw. Black \& Clear Connected 


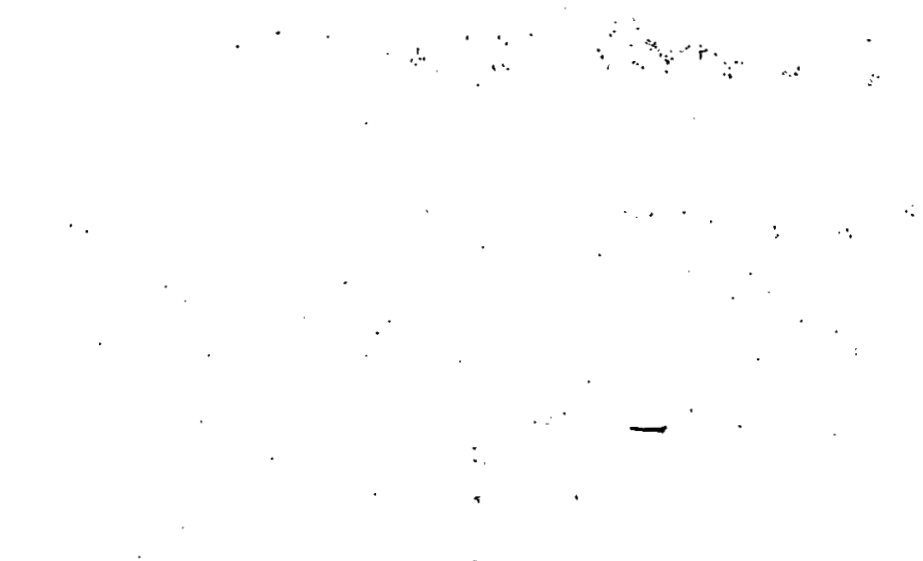

APPENDIX B

LIST OF MANUFACTURERS 


\section{LIST OF MANUFACTURERS}

\section{COMPONENT}

Solar Collectors \& Control System

Solar Hot Water Tank

Solar Pumps $\left(\mathrm{P} 2_{A} \& \mathrm{P}_{B}\right)$

Circulating (Feed) Pump (P1)

Wastewater Pump (P3)

Heat Reclaimer

Diaphragm Control Valves $\left(V_{1}, V_{2}, V_{B}\right)$

Pneumatic Control Valves $\left(V_{A}, V_{3}, V_{4}\right)$

*Electric Control Valve $\left(\mathrm{V}_{\mathrm{S}}\right)$

* Level Controls $\left(L_{1}, L_{2}, L_{3}, L_{4}\right)$

* Temperature Controls $\left(T_{1} \& T_{2}\right)$

* All supplied at no cost to the contract.

\section{MANUFACTURER}

Ying Manufacturing Corporation 1940 West 144th Street

Gardena, C.A. 90249

(213) $770-1756$

Century Plastics, Inc. 1210 North Tustin Avenue Anaheim, CA. (714) $582-7806$

Grundfos Purnp Corporation 2555 Clovis Avenue Clovis, CA.

(209) 299-9741

Pacific Pumping Company of Canada 35 Sinclair Avenue

Georgetown, Ontario, Canada

Hydr-O-Matic Pump Division

P.O. Box 327

Ashland, OH. 44805

Heat Recovery Systems 15925 Minnesota Street Paramount, CA. 90723 (213) 979-0505

ITT Grinnell Valve Division Specialty Valve Group 225 North Front Street Wrightsville, PA. 17638

DeZurik

Sartell, Minnesota

Automatic Switch Company (ASCO) 50-56 Hanover Road

Florharn Park, N.J. 07932 (201) 966-2000

ASCO

ASCO 